\title{
Aspectos tectônicos do emplacement da borda leste do Complexo Granítico Três Córregos, Cerro Azul (PR)
}

\author{
Tectonic aspects at the eastern border of Três Córregos \\ Granitic Complex emplacement, Cerro Azul (PR) \\ Renata Ribas Zanella ${ }^{1}$ e Leonardo Fadel Cury ${ }^{2}$ \\ 1Programa de Pós-Graduação em Geologia, Universidade Federal do Paraná - UFPR, Rua Sanito Rocha, 225, apto. 901, \\ Cristo Rei, CEP 80050-380, Curitiba, PR, BR (ribaszanella@gmail.com) \\ ²Laboratório de Análise de Minerais e Rochas - LAMIR, Universidade Federal do Paraná - UFPR, Curitiba, PR, BR (cury@ufpr.br)
}

Recebido em 29 de março de 2016; aceito em 19 de dezembro de 2016

\begin{abstract}
Resumo
Grandes quantidades de rochas graníticas foram geradas durante a evolução do Ciclo Brasiliano, destacando-se o Complexo Granítico Três Córregos (CGTC), um importante complexo ígneo do Neoproterozoico, intrudido nas rochas metassedimentares mesoproterozoicas da Formação Água Clara. No âmbito da Formação Água Clara reconheceram-se duas associações litológicas: uma constituída por rochas calciossilicáticas e outra composta por mármores calcíticos intercalados a carbonato xistos e filitos. O padrão estrutural observado nessas rochas é caracterizado por duas foliações, onde $\mathrm{S}_{1}$ configura uma clivagem ardosiana que evolui para uma xistosidade contínua, subparalela ao bandamento composicional, observada nos micrólitons de foliação $\mathrm{S}_{2}$ esta desenvolvida em um sistema de transposição parcial a total de $\mathrm{S}_{1}$ em uma tectônica de cavalgamento, resultando em paralelismo entre as duas estruturas. As fácies graníticas Arrieiros-Cerro Azul e São Sebastião reconhecidas na borda leste do CGTC apresentam foliação de fluxo magmático definida pela orientação de máficos da matriz e/ou orientação de fenocristais de feldspato potássico, com atitudes concordantes com os contatos e com as foliações das rochas metassedimentares. Foram reconhecidas paragêneses das fácies xisto verde e anfibolito superior, com gradiente expresso por uma distribuição consistente de minerais índices de temperaturas relativamente mais elevadas em toda a área de estudo. As paragêneses compatíveis com a zona da sillimanita em rochas pelito-aluminosas e calciossilicáticas, a relação dos aspectos petrotectônicos dos granitos com suas encaixantes, bem como os padrões estruturais observados nos granitos e rochas metassedimentares concordantes podem ser explicados pela sobreposição, ao menos parcial, entre os eventos de instalação do CGTC e do desenvolvimento da foliação $\mathrm{S}_{2}$, indicando que os processos iniciais de abertura de espaço para a colocação do CGTC estão relacionados à tectônica de baixo ângulo.
\end{abstract}

Palavras-chave: Complexo Granítico Três Córregos; Granito sin-tectônico; Alojamento de arco magmático; Tectônica de baixo ângulo; Análise estrutural.

\begin{abstract}
During the neoproterozoic collisions related to the ending of Brazilian Cycle, several magmatic events took place in the southern Ribeira Belt, producing large granitic intrusions held in different tectonic environments. The Três Córregos granitic suit is one of the most important magmatic records owing to its expressive and tectonic significance, with several plutons developed in a complex evolution and polyphasic tectonic conditions involving variables during their emplacements. The structural pattern and petrotectonic records of the border of granites and theirs country rocks suggests distinct stages to the emplacement of different facies in the eastern border, were are recognize São Sebastião and Arrieiros - Cerro Azul granitic units (s.l facies), intrude in metavolcano-sedimentary rocks of Agua Clara formation. Those country rocks are associated to mesoproterozoic basins, deformed and metamorphosed during the neoproterozoic history, with early thrust belts stages and to transcurrent shear zones. For the study of the evolution of the Três Córregos granitic suit and related wall rocks in an integrated approach, this research was developed applying structural and petrotectonic analysis together with geophysical data interpretation. The early stages of Apiaí terrane deformation were characterized by a thrust tectonic event, which one developed $\mathrm{S}_{1}$ and $\mathrm{S}_{2}$ foliations in the metavolcanossedimentary rocks of Água Clara formation. The eastern portion of Três Córregos Granitic Suit shows a low dip angle magmatic foliation, even in the regions near by the limits with wall rocks, suggesting an active tectonics condition during the emplacement. The metamorphic records also support this hypothesis, having been generated under pressure and temperature conditions compatible with the overlap of the emplacement processes by the development thrust shear zones.
\end{abstract}

Keywords: Três Córregos Granitic Complex; Syn-tectonic Granite; Magmatic Arc Emplacement; Low Angle Tectonic; Structural Analysis. 


\section{INTRODUÇÃO}

O estudo de cinturões colisionais e o entendimento da evolução geológica de terrenos pré-cambrianos depende, em grande parte, da compreensão dos padrões estruturais, produto das distintas fases de deformação da crosta, bem como das rochas graníticas formadas em diferentes estágios. A maioria dos trabalhos que aborda rochas graníticas busca o significado da ambiência tectônica por meio de estudos litogeoquímicos e geocronológicos, pelos quais podemos reconhecer as assinaturas das fontes e o envolvimento crustal dessas rochas. A implementação das diferentes técnicas busca melhor compreensão dos processos geológicos relacionados ao emplacement dos granitos, posicionando-os na história evolutiva do orógeno.

Arcos magmáticos possibilitam a transmissão de calor em uma taxa relativamente elevada em níveis crustais rasos, produzindo condições metamórficas de alta temperatura e baixa pressão. Estudos realizados em arcos magmáticos, tanto antigos quanto modernos, demonstram que a convecção de calor provido pelo magmatismo é suficiente para produzir cinturões metamórficos de baixa pressão em áreas extensas (Brown, 2009; Hanson, 1995; DeYoreo et al., 1991).

Os modelos numéricos produzidos por Hanson e Barton (1989) indicam que a coalescência de auréolas térmicas a partir de várias intrusões de magmas graníticos pode produzir zonas metamórficas de baixa pressão em escala regional, onde a abundância de intrusões excede $50 \%$ das unidades litosféricas observadas em um cinturão colisional. Em ambientes de arco magmático podem ser observados gradientes térmicos, nos quais temperaturas de alta magnitude não se distribuem de forma generalizada. Modelos que avaliam taxas emplacement $\mathrm{e}$ o gradiente de temperatura em cinturões colisionais sugerem que as temperaturas que estão perto de máximos metamórficos ocorrem por apenas uma pequena fração de tempo em razão do resfriamento rápido das estruturas plutônicas, quando instaladas na litosfera rasa. Avaliando o grande volume de granitos gerados durante a evolução do arco magmático Três Córregos, que apresentam uma história de colocação complexa, compartimentada em diversos estágios, como proposto por Prazeres Filho (2005), pode-se inferir o desenvolvimento de tal condição de baixa pressão em escala regional associada à história de colocação do complexo.

Há muito, diversos autores se aprofundam no estudo das rochas do Pré-Cambriano paranaense, que representa um dos principais sítios com registros geológicos completos sobre a origem e evolução dos orógenos neoproterozoicos relacionados à história da porção ocidental do Gondwana (e.g. Heilbron e Machado, 2003; Schmitt et al., 2004; Heilbron et al., 2008; Siga Jr., 2010). O Cinturão Ribeira é um cinturão orogênico, alongado na direção NE, cuja gênese está relacionada à tectônica neoproterozoica no Gondwana Ocidental. Limitado ao norte pelo Cinturão Araçuaí, estendendo-se para sudeste, pelos estados do Paraná e Santa Catarina, onde é recoberto pelas rochas sedimentares da Bacia do Paraná (Heilbron et al., 2004; Faleiros et al., 2011; Basei et al., 1992; Hasui, 2012).

O principal objetivo deste trabalho foi a investigação estrutural dos termos graníticos alojados na borda leste do Complexo Granítico Três Córregos (CGTC) e das rochas metassedimentares encaixantes pertencentes à Formação Água Clara, além da caracterização do metamorfismo imposto a essas rochas. Essa investigação foi baseada em estudos petrotectônicos e análises integradas e comparativas dos padrões estruturais nos litotipos da região. Para proposição da área de estudos houve a tentativa de evitar a influência de estruturas transcorrentes, pois esta análise está focada na história estrutural pretérita à tectônica de alto ângulo, já discutida e considerada por Basei et al. (1992), Fassbinder (1996), Campanha (2002), Salazar et al. (2013), Hasui (2012) e Faleiros et al. (2010). Sem a influência das transcorrências, esperou-se contribuir para o melhor entendimento de como tiveram início os processos de emplacement dos granitos associados ao arco-magmático Três Córregos e qual a relação com as fases de baixo ângulo registradas nas encaixantes.

\section{CONTEXTO GEOLÓGICO REGIONAL}

Na região do Vale do Ribeira e adjacências, inseridas no contexto da porção centro-sul da Faixa Ribeira Sul, são encontradas atualmente quatro unidades geotectônicas, individualizadas com base em suas distintas características litológicas, estruturais e isotópicas, denominadas de terrenos Apiaí, Curitiba, Luís Alves e Paranaguá, resultantes da colisão entre as Placas do São Francisco, Congo, Paranapanema e Rio de La Plata, durante a amalgamação do supercontinente Gondwana Ocidental (Basei et al., 1992; Siga Jr. et al., 1995). Durante os processos neoproterozoicos, desenvolveram-se inicialmente sistemas de cavalgamento, com geração de lascas e nappes, imprimindo às unidades feições lenticularizadas e sigmoidais quando observadas em mapas. O sistema de falhas transcorrentes destrais instalado após, ou em parte tardio aos cavalgamentos, é o principal responsável pelo controle da estruturação observado no Cinturão, sobrepondo deformações (Hasui, 2012; Basei et al., 1992; Faleiros et al., 2011). A estruturação geral do Cinturão Ribeira é orientada na direção N35E no oeste do Terreno Apiaí, chegando gradativamente a N55E nos Terrenos Curitiba e Paranaguá (Hasui, 2012).

O Terreno Apiaí constitui uma faixa de aproximadamente $500 \mathrm{~km}$ de extensão e $100 \mathrm{~km}$ de largura, composta por terrenos datados do Calymmiano, Toniano e Ediacarano (Prazeres Filho et al., 2003; Heilbron et al., 
2004). Inclui assembleias litológicas de retroarco, depósitos de plataforma carbonática, turbiditos e depósitos de águas profundas com magmatismo máfico associado (Faleiros et al., 2011; Weber et al., 2004; Siga Jr. et al., 2003, 2011). Dentre as rochas graníticas destacam-se, em dimensão, os batólitos pertencentes aos complexos Cunhaporanga, Três Córregos e Agudos Grandes, de idades neoproterozoicas (Prazeres Filho et al., 2003; Janasi et al., 2001), apresentados na Figura 1.

O CGTC é um corpo multi-intrusivo, com formato alongado na direção aproximada $\mathrm{N} 50 \mathrm{E}$, apresentando cerca de $100 \mathrm{~km}$ de comprimento e $25 \mathrm{~km}$ de largura (Fuck et al., 1967; Gimenez Filho, 1993; Prazeres Filho, 2000, 2005). Seu limite a oeste, com o Grupo Itaiacoca, se dá por meio da Zona de Cisalhamento Itabirapuã, e a leste, com a Formação Água Clara, por meio de contatos principalmente intrusivos, sendo observados contatos tectônicos locais. Ao norte e ao sul os contatos são feitos com a Formação Furnas da Bacia do Paraná (Gimenez Filho et al., 1995; Prazeres Filho et al., 2003). Estudos geoquímicos e isotópicos classificam as rochas do CGTC como pertencentes a uma suíte cálcio-alcalina predominantemente metaluminosa, de médio a alto $\mathrm{K}$, com assinaturas litogeoquímicas compatíveis com os granitos de tipologia I (Gimenez Filho, 1993; Prazeres Filho, 2000, 2005). São reconhecidos granitos alcalinos com aspectos intrusivos nas demais unidades, a exemplo dos granitos Joaquim Murtinho e Barra do Santana, considerados, por Prazeres Filho (2005), granitoides anorogênicos posteriores ao CGTC.

Com base em características isotópicas (litogeoquímica e geocronologia) e texturais, Prazeres Filho (2005) propõe a individualização de sete unidades graníticas no CGTC, sendo elas: Santa Bárbara, Barra do Chapéu - Ribeirão Branco, São Sebastião, Conceição, Arrieiros - Cerro Azul, Apiaí-Guaçu e Paina. A partir da integração de dados de vários métodos geocronológicos (U-Pb em zircões por thermal ionization mass spectrometry isotopic dilution (ID - TIMS) e sensitive high mass-resolution ion microprobe (SHRIMP, Sm-Nd e $\mathrm{Rb}-\mathrm{Sr}$ ), Prazeres Filho (2005) propõe que os granitos cálcio-alcalinos de médio K, com idades entre 650 e $620 \mathrm{Ma}$ - tonalitos da Unidade Paina e quartzo monzodioritos da Unidade Apiaí-Guaçu -, sejam remanescentes do magmatismo pré-colisional, sendo os principais representantes do arco magmático. Já os granitos cálcio-alcalinos a alto $\mathrm{K}$, de idades entre 620 e $590 \mathrm{Ma}$ - Unidades Arrieiros Cerro Azul, Conceição, São Sebastião, Barra do Chapéu Ribeirão Branco - , representam o magmatismo sin a tardi colisional, gerados em ambiente compressional relacionados à evolução do arco magmático.

A Formação Água Clara, proposta por Marini et al. (1967), é uma faixa alongada na direção NE-SW, limitada a norte pela Zona de Cisalhamento Itabirapuã e balizada ao sul pelas zonas de cisalhamento Quarenta-Oitava e Morro
Agudo (Siga Jr., 2010). Sua posição estratigráfica foi, e ainda é, debatida por diversos autores (e.g. Silva e Algarte, 1981; Fritzsons et al., 1982; Schöll et al., 1982; Fassbinder, 1996; Faleiros et al., 2012). A formação é composta predominantemente por rochas carbonáticas (mármores puros e impuros), filitos, xistos carbonáticos, quartzitos, metabasitos e anfibolitos (Marini, 1970; Siga Jr., 2010; Weber et al., 2004). Pontes (1982) divide a Formação Água Clara em duas fácies. A unidade basal, de natureza vulcanossedimentar, é composta por quartzo-mica xistos com clorita, biotita, muscovita e quartzo, com intercalações de rochas metabásicas, metavulcânicas, quartzitos, metamargas, mármores impuros e metacherts. Uma característica marcante nesta unidade, segundo Pontes (1982), é a intercalação frequente com níveis de formações ferríferas bandadas. A unidade superior é essencialmente carbonática, com mármores foliados e micáceos com poiquiloblastos de titanita, e intercalações de quartzo-mica xistos e quartzitos. Os quartzo-mica xistos são compostos por quartzo, biotita, clorita e sericita. Nessa unidade ocorrem ainda calcoxistos compostos por quartzo, biotita, clorita, sericita, granada e epidoto. A deposição dessa formação ocorreu em ambiente de plataforma relativamente profunda (Weber et al., 2004), com vulcanismo associado. As idades $\mathrm{U}-\mathrm{Pb}$ em núcleos de zircão das rochas metabásicas indicaram formação mesoproterozoica (c.a. $1500 \mathrm{Ma}$ ) e, em bordas de zircão, idades de c.a. $590 \mathrm{Ma}$, representando idades de metamorfismo regional no Neoproterozoico (Weber et al., 2004; Siga Jr., 2010; Siga Jr. et al., 2011).

\section{MATERIAIS E MÉTODOS}

Para este estudo, foram utilizados dados estruturais dos corpos graníticos da borda leste do CGTC e das encaixantes metassedimentares da Formação Água Clara, analisados em conjunto com mapas aerogeofísicos de gamaespectrometria, estes para identificar a distribuição espacial das unidades geológicas da área. Foram utilizados dados aerogamaespectrométricos do "Projeto Aerogeofísico Paraná - Santa Catarina" (CPRM, 2011), com levantamentos de altura média de voo de $100 \mathrm{~m}$, linhas de direção N-S com espaçamento de $500 \mathrm{~m}$, e linhas E-W com espaçamento de $10.000 \mathrm{~m}$. O tratamento dos dados foi realizado pelo Laboratório de Pesquisas em Geofísica Aplicada da Universidade Federal do Paraná (LPGA - UFPR). A análise dos dados estruturais focou no reconhecimento e na compreensão do padrão das foliações e lineações internas ao CGTC para posterior comparação e correlação com o padrão regional observado nas rochas encaixantes nas proximidades de sua borda leste, por meio de análise multiescala e multitemática, como Sistema de Informação Geográfica (SIG), trabalhos de campo e análise petrográfica. 


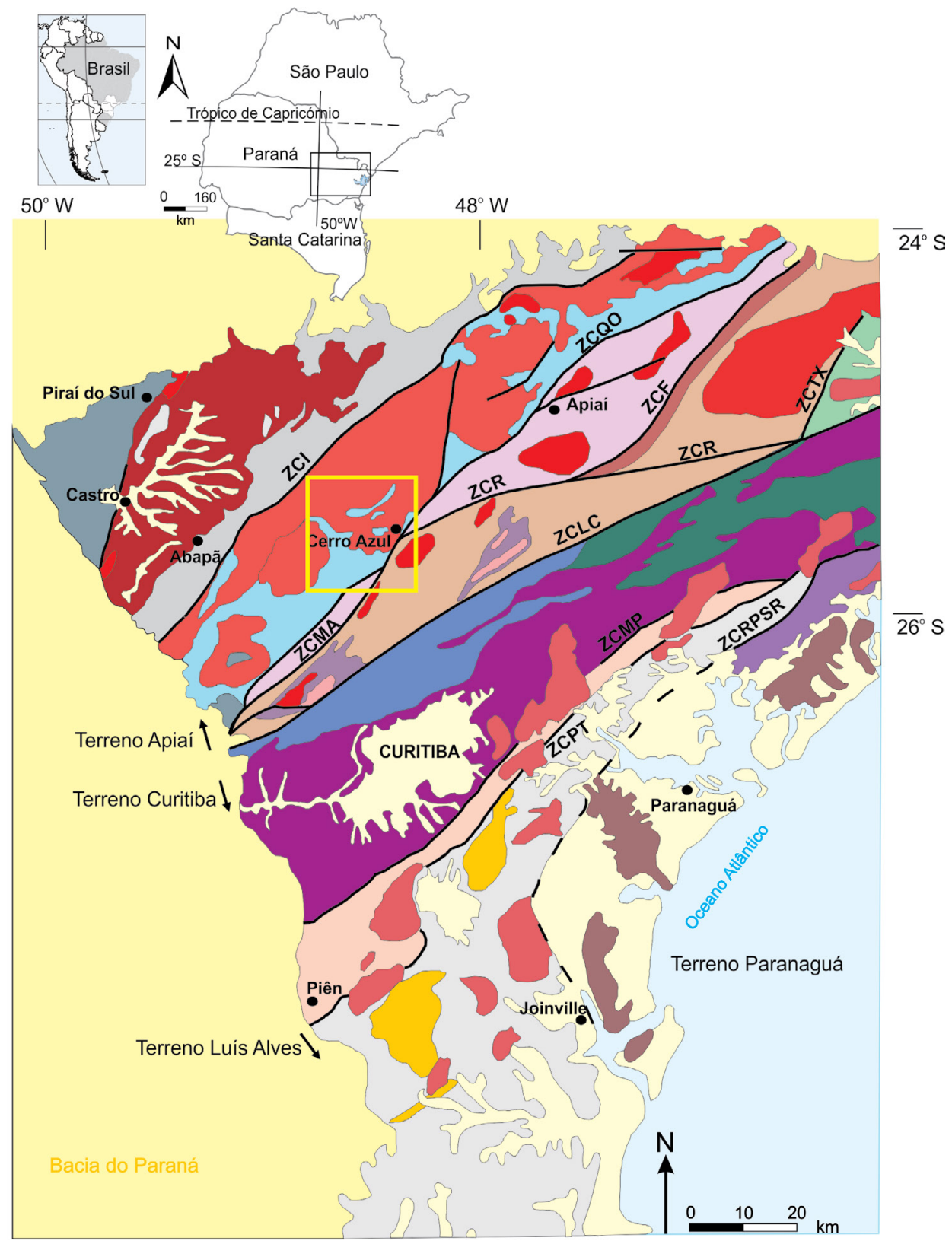

Cobertura fanerozoica $\square$ Bacias eopaleozoicas $\square$ Bacias neoproterozoicas Stocks graníticos do Domínio Apiaí Batólitos graníticos cálcio-alcalinos neoproterozoicos: $\square$ Granitos alcalinos da Província Graciosa Batólito granítico Cunhaporanga Complexo granítico Três Córregos Batólito Agudos Grandes $\square$ Cinturão granítico Piên-Mandirituba $\square$ Rochas do Terreno Paranaguá Terreno Apiaí: $\square$ Grupo Itaiacoca $\quad \square$ Formação Água Clara $\square$ Subgrupo Lajeado $\square$ Formação Votuverava $\square$ Formação Iporanga $\square$ Formação Perau Núcleos granito-gnaíssicos Terreno Curitiba: —Formação Capiru \Formação Turvo-Cajati Complexo Atuba Terreno Luís Alves: $\quad \square$ Complexo Granulítico de Santa Catarina Terreno Serra do Mar: $\square$ Sequência Rio das Cobras $\square$ Rochas do Terreno Embu

\section{Área de estudo}

Fonte: figura modificada de Prazeres Filho et al. (2003), Cury et al. (2008) e Zanella (2016).

ZCRPSR: Zona de Cisalhamento Rio Palmital-Serrinha; ZCPT: Zona de Cisalhamento Piên-Tijucas; ZCMP: Zona de Cisalhamento Mandirituba-Piraquara; ZCTX: Zona de Cisalhamento Taxaquara; ZCLC: Zona de Cisalhamento Lancinha-Cubatão; ZCMA: Zona de Cisalhamento Morro Agudo; ZCR: Zona de Cisalhamento Ribeira; ZCQO: Zona de Cisalhamento Quarenta-Oitava; ZCl: Zona de Cisalhamento Itabirapuã.

Figura 1. Mapa geológico da constituição parcial da Faixa Ribeira Sul, com os Terrenos Apiaí, Curitiba, Luís Alves e Paranaguá. 
O tratamento dos dados estruturais da borda centro-leste do CGTC foi realizado no software OpenStereo (Grohmann e Campanha, 2010), via estereogramas setorizados, utilizando rede de projeção no hemisfério inferior em igual área de Schmidt-Lambert.

O estudo petrográfico objetivou a caracterização da mineralogia, das texturas e das estruturas dos litotipos da área, para posterior distinção de estruturas de fluxo magmático das rochas graníticas e da deformação regional impressa nas rochas graníticas e encaixantes, utilizando a análise microtectônica (Passchier e Trouw, 2005; Trouw et al., 2010; Vernon, 2004).
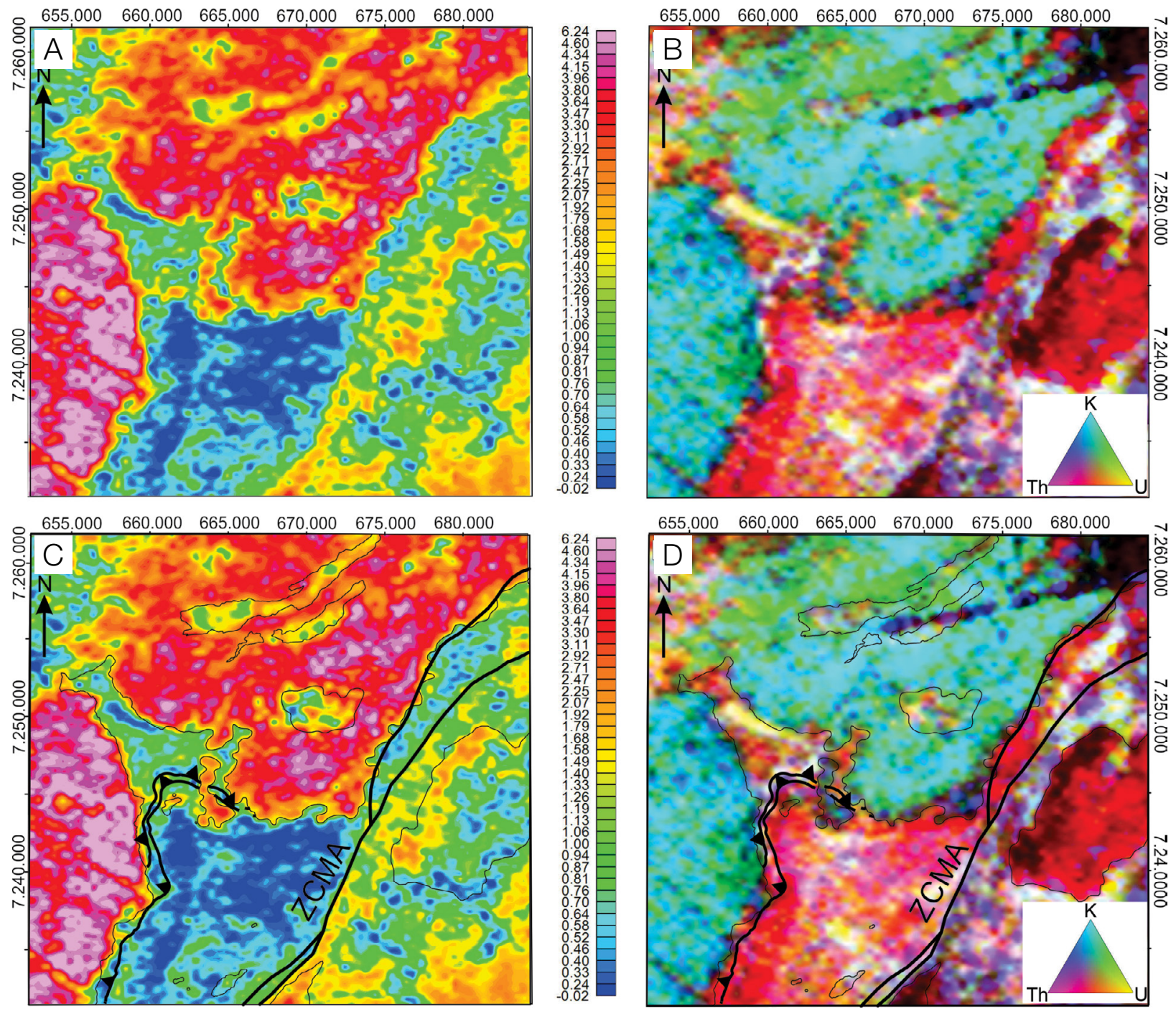

\section{GRANITOS E ENCAIXANTES NA BORDA LESTE DO COMPLEXO GRANÍTICO TRÊS CÓRREGOS}

Na região foram delimitadas, por meio da caracterização litológica e da análise da distribuição espacial, três unidades de rochas metassedimentares. Duas delas são associadas à Formação Água Clara (Associação Litológica Calciossilicática e Associação Litológica Carbonato-silicática), conforme Figuras 2 e 3, e a terceira à Formação Votuverava. As duas associações litológicas da Formação Água Clara foram individualizadas com base nas relações internas de contato entre os seus litotipos e pela análise de mapas aerogeofísicos

ZCMA: Zona de Cisalhamento Morro Agudo.

Figura 2. Mapa esquemático com as associações litológicas propostas. (A) mapa aerogamaespectrométrico de anomalia de potássio (\%); (B) mapa aerogamaespectrométrico de anomalia da composição ternária CMY dos três radionuclídeos (\% K, ppm eU, ppm eTh); (C) mapa aerogamaespectrométrico de anomalia de potássio (\%), com sobreposição dos principais contatos e estruturas; (D) mapa aerogamaespectrométrico de anomalia da composição ternária CMY dos três radionuclídeos (\% K, ppm e U, ppm e Th), com sobreposição dos principais contatos e estruturas. Sistema de projeção cartográfico: SIRGAS2000, UTM zona 22 S. 
de anomalias gamaespectrométricas de $\mathrm{K}$, evidenciando assinaturas geofísicas características e distintas entre si. Os mapas aerogamaespectrométricos mostraram, ainda, variação faciológica dos termos graníticos (Figura 2A). Quando analisados em conjunto com mapas de anomalias CMY (Figura 2B) e CT, balizados por dados de campo,

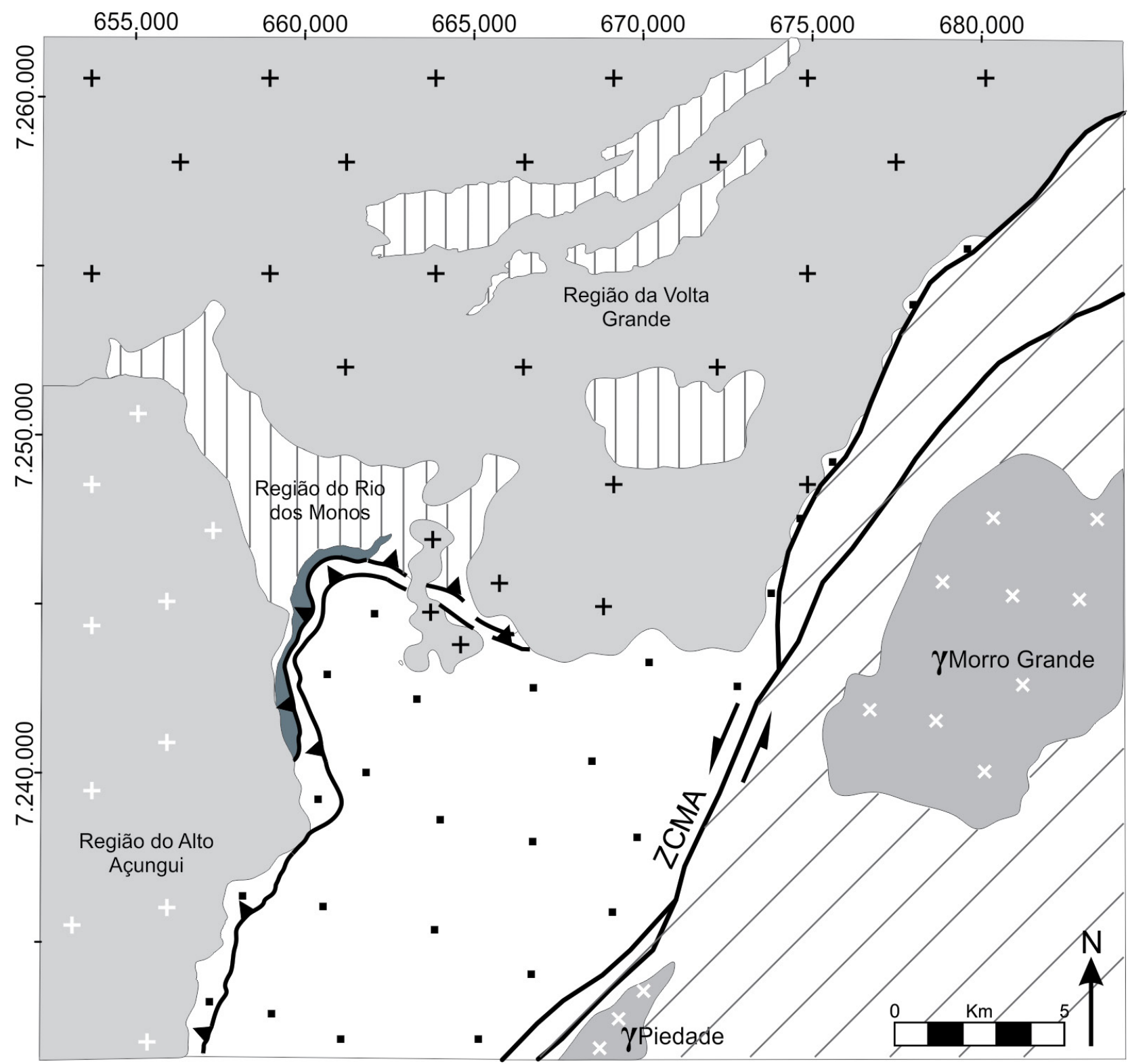

Zona de Cisalhamento Morro Agudo (transcorrente sinistral)

Formação Água Clara - Associação Litológica Calciossilicática

- Formação Água Clara - Associação Litológica Carbonato-silicática

$\$$ Zona de cavalgamento

-

+ Complexo Granítico Três Córregos - Fácies Arrieiros - Cerro Azul Formação Votuverava

Complexo Granítico Três Córregos - Fácies São Sebastião

Figura 3. Mapa geológico simplificado da área de estudo, com as associações litológicas propostas para a Formação Água Clara e as fácies graníticas constituintes do Complexo Granítico Três Córregos aflorantes. Sistema de projeção cartográfico: SIRGAS2000, UTM zona $22 \mathrm{~S}$. 
permitem traçar com bastante precisão o contato do granito com as rochas metassedimentares (Figuras 2C e 2D).

A Associação Litológica Calciossilicática apresenta assinaturas geofísicas de anomalias de $\mathrm{K}$ com valores moderados (Figuras 2A e 2C), sendo composta porlitotipos predominantemente silicáticos e calciossilicáticos, aflorantes na região de Volta Grande, no norte da área de estudo, configurando uma lasca de rochas metassedimentares de direção geral N60E, em meio ao CGTC, e pelas rochas metassedimentares de direção geral N40W na porção oeste (Rio dos Monos). Essa unidade é caracterizada pela intercalação de camadas métricas de rochas calciossilicáticas com níveis de composição carbonatossilicática, além de intercalações com rochas carbonáticas (como mármores puros e impuros) de espessuras variadas (milimétrica a decimétricas), e associações terrígenas (como quartzito e quartzo-sericita filito e biotita/muscovita xisto), em contatos aparentemente transicionais. Em meio aos litotipos dessa associação, frequentemente são observados níveis de ortoanfibolitos, com destaque para corpo anfibolítico tabular, de dimensão expressiva, localizado junto ao contato entre as duas associações (Figura 3). Próximo a esse corpo encontra-se uma rocha calciossilicática bandada, composta por quartzo, epidoto, plagioclásio e anfibólio, com ocorrências de tremolita fibrorradiada em níveis preferenciais.

Destaca-se a ocorrência de xistos aluminosos, com grande variedade composicional, destacando a presença de cianita, estaurolita, andaluzita, cordierita, granada, grafita e magnetita.

Os níveis de mármores puros são caracterizados por bandamento composicional centimétrico a métrico de níveis compostos essencialmente por calcita, intercalado a mármores impuros, compostos por calcita, quartzo, muscovita, biotita, anfibólio, flogopita, clorita, óxido de ferro e manganês, por vezes intercalado a níveis essencialmente quartzosos. O contato entre os níveis é gradacional quanto à composição e, algumas vezes, quanto à textura. As rochas dessa unidade apresentam granulação fina a grossa e textura granoblástica a granolepidoblástica.

A Associação Litológica Carbonato-silicática, cujas assinaturas geofísicas são caracterizadas por valores muito baixos de K (Figuras 2A e 2B), é composta predominantemente por rochas carbonáticas localizadas na região do Alto Açungui. O contato entre as duas associações é marcado por cavalgamentos (Figura 3). Essa associação é composta por níveis centimétricos a métricos de mármores calcíticos puros e mármores impuros, constituídos por quantidades variáveis de calcita, quartzo, clorita, margarita, muscovita, tremolita, óxido, pirita e biotita, intercalados a corpos métricos a decimétricos de xistos compostos por biotita, muscovita, quartzo, plagioclásio, sillimanita, clorita, minerais opacos e carbonato (calco-xistos), de textura lepidoblástica. No contato dos xistos com o CGTC desenvolve-se uma aparente auréola de contato, com espessuras varáveis, podendo alcançar $1 \mathrm{~km}$. O muscovita hornfels apresenta bandamento composicional decimétrico de níveis mais quartzosos e mais micáceos (muscovita/biotita), com contatos graduais entre si. Os cristais de muscovita e biotita desenvolvidos no metamorfismo de contato podem alcançar $2 \mathrm{~mm}$ de comprimento. Localmente é possível observar foliação incipiente nas rochas dessa unidade, caracterizada pela fraca orientação de muscovita e biotita.

$\mathrm{Na}$ área de estudo, as litologias aflorantes pertencentes à Formação Votuverava são mármores, filitos, quartzitos e xistos, ao longo do traçado da Zona de Cisalhamento Morro Agudo (ZCMA). Os mármores, de cor cinza e granulação muito fina a fina, são caracterizados por apresentarem bandamento com variações de resistência diferencial à dissolução, o que ressalta as variações composicionais da rocha. Sua composição mineral é formada predominantemente por calcita e quartzo, com traços de pirita. Frequentemente são observadas vênulas submilimétricas e centimétricas de calcita bem cristalizada.

Os filitos, de coloração castanha a avermelhada e granulação fina, são compostos essencialmente por clorita, quartzo, magnetita e sericita. A textura dessas rochas é lepidoblástica, caracterizada pela orientação de sericita e clorita. Subordinadamente ocorrem níveis xistosos definidos pela presença de muscovita. Intercalações de níveis de composição carbonatossilicática são observadas, com plagioclásio, piroxênio e carbonato.

Na região estudada, o CGTC é representado pelas fácies graníticas denominadas São Sebastião e Arrieiros - Cerro Azul (seguindo a proposta de Prazeres Filho, 2000, 2005), cartografadas com base em variações composicionais e texturais. A fácies São Sebastião aflora na porção sudeste da área de estudo, sendo caracterizada pelo predomínio de ocorrências de composições monzograníticas a quartzo monzoníticas, ambas de textura predominantemente porfirítica em meio a matriz média a grossa, de textura hipidiomórfica. Os fenocristais de feldspato potássico são, na maioria, euédricos (tabulares) e apresentam dimensões centimétricas com média de $4 \mathrm{~cm}$, alcançando até $8 \mathrm{~cm}$, com geminação simples, macropertitas, zonamento e inclusões de máficos. Com frequência são observados concentrados de fenocristais de feldspato potássico, configurando feições crowded e cumulática, que podem apresentar ou não orientação. As feições cumuláticas são observadas em níveis métricos com aumento gradativo da porcentagem de fenocristais de feldspato potássico, com contatos mútuos frequentes, chegando entre 90 e $95 \%$. O contato com as rochas encaixantes é intrusivo, com geometrias retilíneas ou lobados, e concordante a subparalelo à foliação principal observada nessas rochas (Figuras 4A a 4D). Tais rochas encaixantes, nas proximidades das zonas de contato, apresentam cristais de 

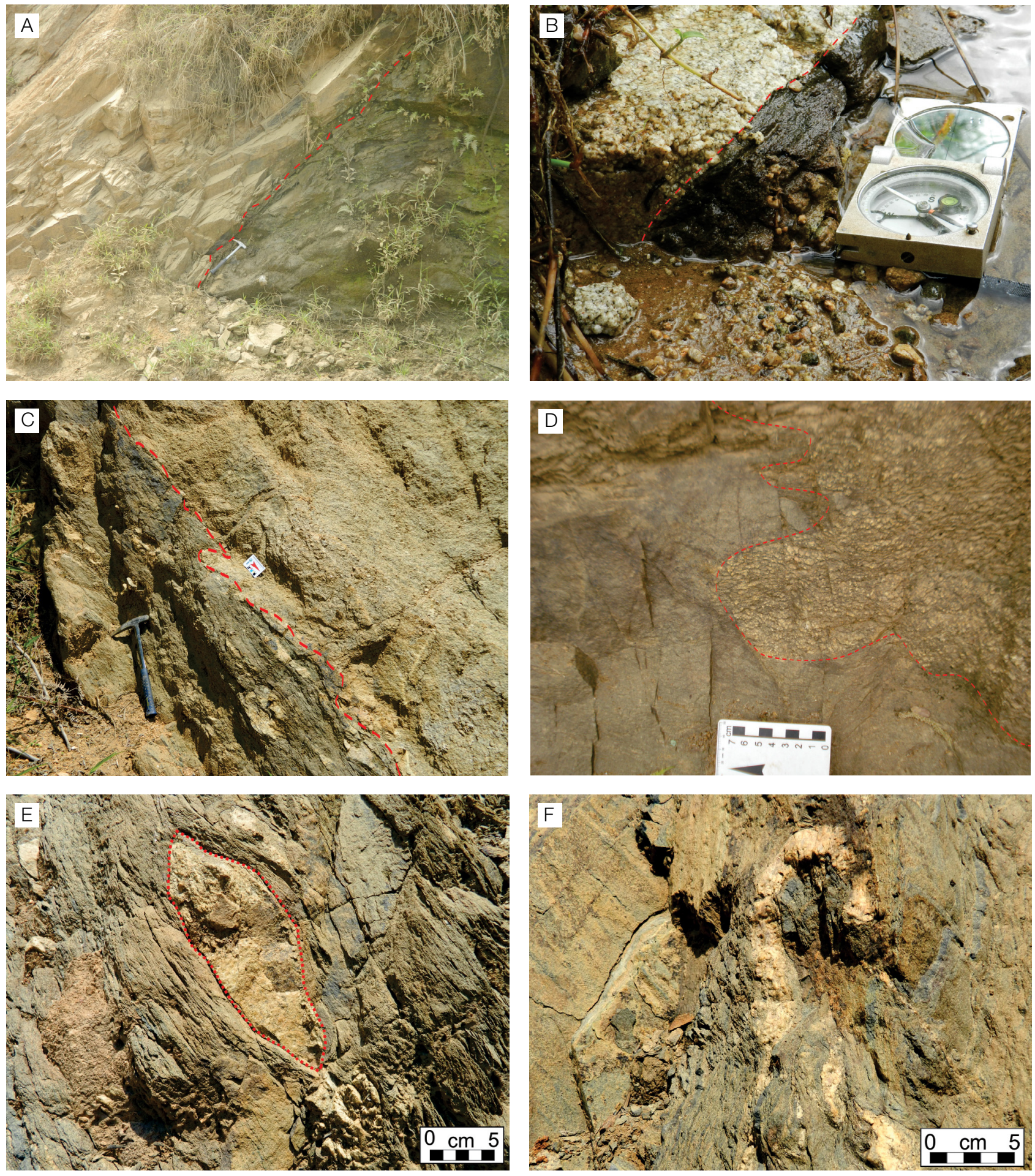

\section{:.... Contato entre granitos e encaixantes}

Figura 4. Contatos e relação de viscosidade entre as rochas graníticas e metassedimentares encaixantes. (A) contato retilíneo entre monzogranito porfirítico e biotita-quartzo-muscovita xisto; (B) contato retilíneo entre leucogranito sienogranítico com calciossilicática; (C) contato ondulado a lobado entre monzogranito e calciossilicática; (D) contato lobado entre monzogranito porfirítico e muscovita-quartzo xisto; (E) lente de composição monzogranítica boudinada em meio à foliação $S_{2}$ de rocha calciossilicática; $(F)$ veio sienogranítico em meio à rocha calciossilicática, com dobra sem raiz. 
muscovita e de biotita de granulação média sem orientação preferencial, desenvolvidos no sistema de hornfels (região do Alto Açungui). Em alguns locais, pode ser observado contato tectônico entre granitos e rochas encaixantes, marcado por falha de cavalgamento e colocando lado a lado quartzo-muscovita xisto e monzogranito porfirítico (Figura 5).

Já a fácies Arrieiros - Cerro Azul, de ocorrência predominante na área, apresenta predomínio de monzogranitos porfiríticos em matriz idiomórfica média a grossa, caracterizados pela coloração castanho avermelhada e sendo comumente encontrados termos de composição sienogranítica, granodiorítica, diorítica, monzonítica e quartzo monzonítica. Os fenocristais de feldspato alcalino são euédricos, tabulares, podem alcançar $7 \mathrm{~cm}$ de comprimento de maior eixo e geralmente apresentam coloração rosada a avermelhada, sendo facilmente distinguidos dos da fácies São Sebastião. O contato dessa fácies com as rochas encaixantes se faz predominantemente de maneira intrusiva, com limites concordantes à foliação principal observada nessas rochas, e contatos retilíneos a lobados. Muitas vezes o contato se faz através de intercalações entre faixas centimétricas a métricas de rocha metassedimentar e faixas de granito, especialmente na grande lasca de metassedimento do nordeste da área de estudo. Contatos tectônicos pontuais por falha de cavalgamento dúctil são observados (região de Volta Grande), onde há presença de vênulas e aplitos de leucogranito sienogranítico em meio às rochas metassedimentares, com direções próximas ou coincidentes com o bandamento composicional e à foliação $\mathrm{S}_{2}$. Nas proximidades do contato, o quartzo monzonito apresenta foliação pronunciada, em que são observados augens de fenocristais de feldspato potássico e leve estiramento de cristais de quartzo da matriz (atitude foliação $\mathrm{S}_{\mathrm{m}} \mathrm{N} 40 \mathrm{E} / 60 \mathrm{NW}$ ), orientados de maneira geral, paralelos ao contato e à foliação $\mathrm{S}_{2}$ observada na calciossilicática encaixante (atitude da foliação $\mathrm{S}_{2} \mathrm{~N} 60 \mathrm{E} / 50 \mathrm{NW}$ ). Os aplitos e as vênulas apresentam dobras de arrasto (Figura 4E), com flancos rompidos e boudinadas (lx boudin 355/55), conforme Figura 4F, estruturas pinch-and-swell e em gash veins.

Essas feições de intercalação entre as rochas graníticas e metassedimentares, com porções mutuamente englobadas e contatos lobados, indicam que a viscosidade das rochas graníticas era muito próxima à das metassedimentares.

\section{PADRÕES ESTRUTURAIS}

Para melhor entendimento do contexto estrutural, os dados foram distribuídos e tratados em três diferentes setores com situações geológicas distintas, caracterizadas e reconhecidas
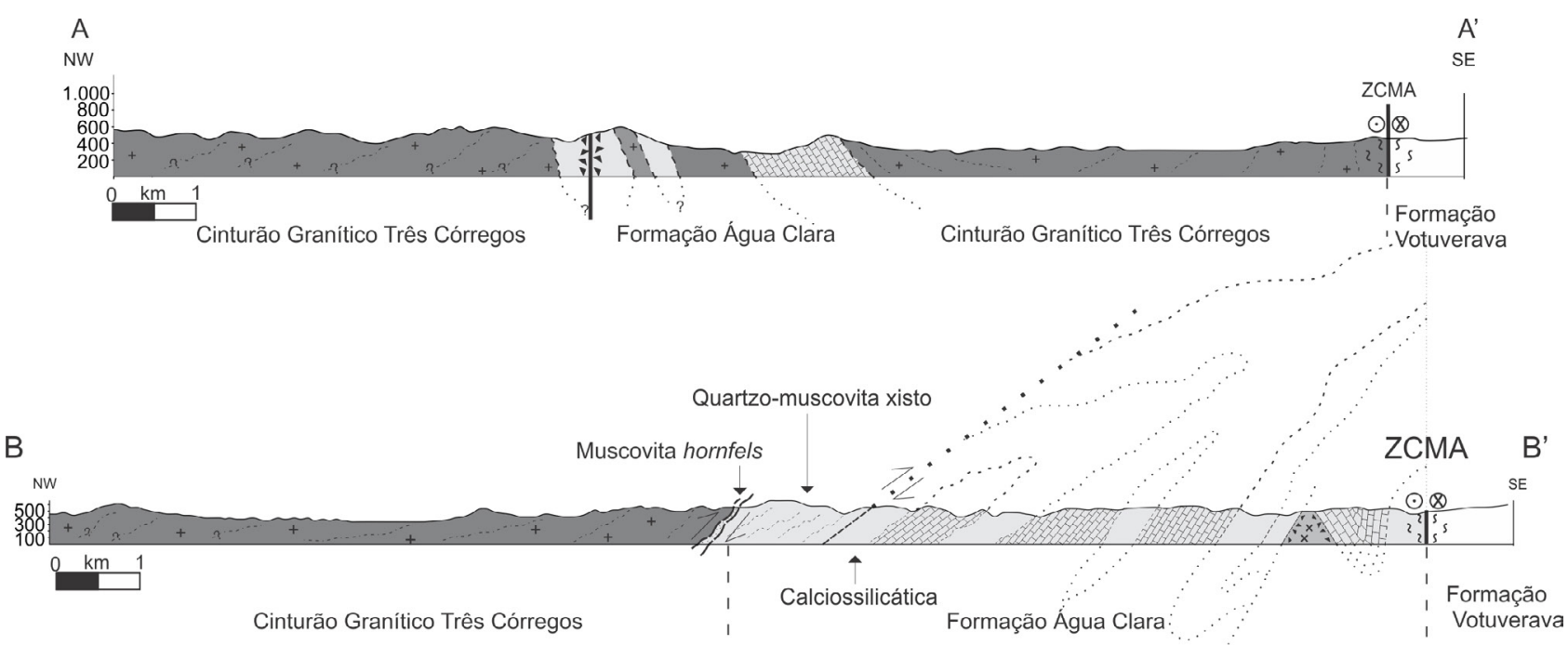

\footnotetext{
ss Zona de milonitização Zona de brecha de falha ... . Foliação de fluxo magmático

1/ Zona de Cisalhamento Morro Agudo (transcorrência sinistral) / Contato definido ,' Contato aproximado ?? Contato inferido

Cinturão Granítico Três Córregos Metassedimentos da Formação Água Clara Mármore calcítico bandado da Formação Água Clara

Formação Votuverava $\quad$ × Granito Taici
}

ZCMA: Zona de Cisalhamento Morro Agudo.

Figura 5. Perfis geológicos da região de Volta Grande ( $\left.A-A^{\prime}\right)$ e do Alto Açungui (B - B'). O contato do Complexo Granítico Três Córregos na região de Volta Grande é caracterizado por lascas de metassedimentos intercaladas com granitos; na região do Alto Açungui o contato é caracterizado por zonas de cavalgamento. 
pela análise de mapas geológicos e imagens geofísicas, bem como pelos padrões estruturais observados (Figura 4). Em terrenos policíclicos, a compartimentação tectônica é de fundamental importância para construção de estereogramas. Sem ela, o produto pode ser expresso por figuras com direções variadas, com apenas uma tendência principal com "variações" e sem diagnósticos conclusivos de tendências secundárias. Os limites dos setores não são caracterizados por uma estrutura física mapeável, e sim pelo contexto das estruturas regionais, bem como pela mudança percebida no padrão geológico-estrutural. No estudo das estruturas relacionadas à colocação de cinturões graníticos, diagramas setorizados demonstram melhor as variações locais e os padrões regionais dos campos de tensão, possibilitando melhor compreensão dos registros estruturais, suas correlações petrotectônicas e, consequentemente, melhor modelagem tectônica. $\mathrm{O}$ tratamento dos dados estruturais da borda centro-leste do CGTC validou a proposta de compartimentação, na qual os três setores mostram diferenças geológicas na relação granito-encaixante, sendo também caracterizados por variações geométricas na tendência geral da direção das foliações, bem como pela variação no desenvolvimento de $\mathrm{S}_{1}, \mathrm{~S}_{2}$ e $\mathrm{S}_{\mathrm{c}}$.

O Setor I, na região de Volta Grande (Figura 6), é caracterizado por megaenclaves e lascas de rochas metassedimentares com formas alongadas, rompidos envoltos em meio a rochas graníticas, e a elas intercalados. São observadas estruturas hidrotermais e evidências de metamorfismo termal, contudo, sem apagar os registros das estruturas, que apresentam padrão coerente em toda a sua extensão. O Setor II, na região do Rio dos Monos, apresenta-se como uma área onde a borda do CGTC apresenta traço irregular, com uma série de reentrâncias e engolfamentos, que, a grosso modo, acompanham o traçado de uma dobra de escala regional com eixo de direção aproximada N40W (Figura 6). Destaca-se que dobras com eixo nesta direção são raras no contexto estrutural da região, o que chama ainda mais a atenção para as características desse setor. O Setor III, do Alto Açungui, é caracterizado pelo contato do CGTC com as encaixantes da Formação Água Clara com delineado regular (Figura 6), contudo, ainda sinuoso, onde destaca-se a coexistência de estruturas de baixo ângulo tanto nas encaixantes quanto nos granitos. Também nessa região pode ser observado metamorfismo de contato desenvolvido em uma aparente auréola, em uma faixa de aproximadamente $1,5 \mathrm{~km}$ a partir do contato com o CGTC.

\section{Geologia estrutural das rochas metassedimentares}

De modo geral, as rochas metassedimentares da área de estudo apresentam bandamento composicional, que pode ser, em alguns casos, considerado original da sedimentação destas rochas. Em relação aos produtos das deformações impostas a essas rochas, o padrão estrutural é caracterizado pelo desenvolvimento de duas foliações, $\mathrm{S}_{1}$ e $\mathrm{S}_{2}$, originalmente de baixo ângulo, afetadas por uma tectônica de alto ângulo. Ocorrem feições protomiloníticas associadas a zonas de cisalhamento de baixo ângulo, registradas em estruturas manteadas do tipo sigma, observadas em cristais de feldspato (potássico e plagioclásio) e de quartzo, além de boudins assimétricos em cristais de quartzo. O sentido de movimento dessas estruturas indica vergência para sudeste.

\section{Foliação $S_{1}$}

A foliação $S_{1}$ é definida pela orientação em planos paralelos a subparalelos de cristais de sericita, clorita, tremolita, diopsídio e quartzo. Apresenta-se paralela a subparalela ao bandamento composicional, com espaçamento submilimétrico a milimétrico, configurando clivagem ardosiana ou xistosidade contínua. Seu desenvolvimento é melhor reconhecido em rochas de textura lepidoblástica (filitos e xistos). Nas rochas de textura nematoblástica (calciossilicáticas) e granoblástica (mármores), essa foliação é fracamente desenvolvida em razão da reologia do material, sendo evidenciada nos níveis de composição silicática intercalados.

Localmente, a foliação $\mathrm{S}_{1}$ é reconhecida como plano axial de microdobras $\left(\mathrm{F}_{1}\right)$ isoclinais a cerradas, em bainha, comumente apresentando flancos rompidos, sendo intrafoliares ao bandamento composicional. Essas dobras não são penetrativas à área de estudo e apresentam elevada dificuldade de reconhecimento em razão de suas dimensões milimétricas e obliteração por fases de deformação superimpostas.

Ela apresenta-se crenulada por microdobras de baixa amplitude e comprimento de onda, com flancos assimétri$\cos \left(\mathrm{F}_{2}\right)$. Devido à diferença de reologia observada entre os níveis que compõem o bandamento composicional, as crenulações observadas frequentemente são desarmônicas. Os ângulos interflancos, entre 10 e $60^{\circ}$, as caracterizam como dobras abertas e fechadas. Pode-se observar espessamento de charneira e adelgaçamento de flancos conforme evolui a transposição dessas superfícies pela foliação $S_{2}$, chegando a originar dobras sem raiz (de flancos rompidos).

\section{Foliação $S_{2}$}

Essa foliação é penetrativa a todos os afloramentos da área, sendo definida pela orientação de cristais de biotita, sericita e muscovita em planos subparalelos ao bandamento composicional, de espaçamento milimétrico a centimétrico. Caracteriza um sistema de transposição parcial (Figura 7A) a total da foliação $S_{1}$, sendo classificada como clivagem de crenulação (Figura 7B), clivagem ardosiana ou xistosidade. 
Em razão desse sistema de transposição característico do desenvolvimento da foliação $S_{2}$, em alguns locais ocorre a completa obliteração de $\mathrm{S}_{1}$ (Figura 7C).
Localmente é reconhecido o caráter milonítico dessa foliação, caracterizada por planos anastomosados, lenticularizados e descontínuos, associados a dobras com flancos

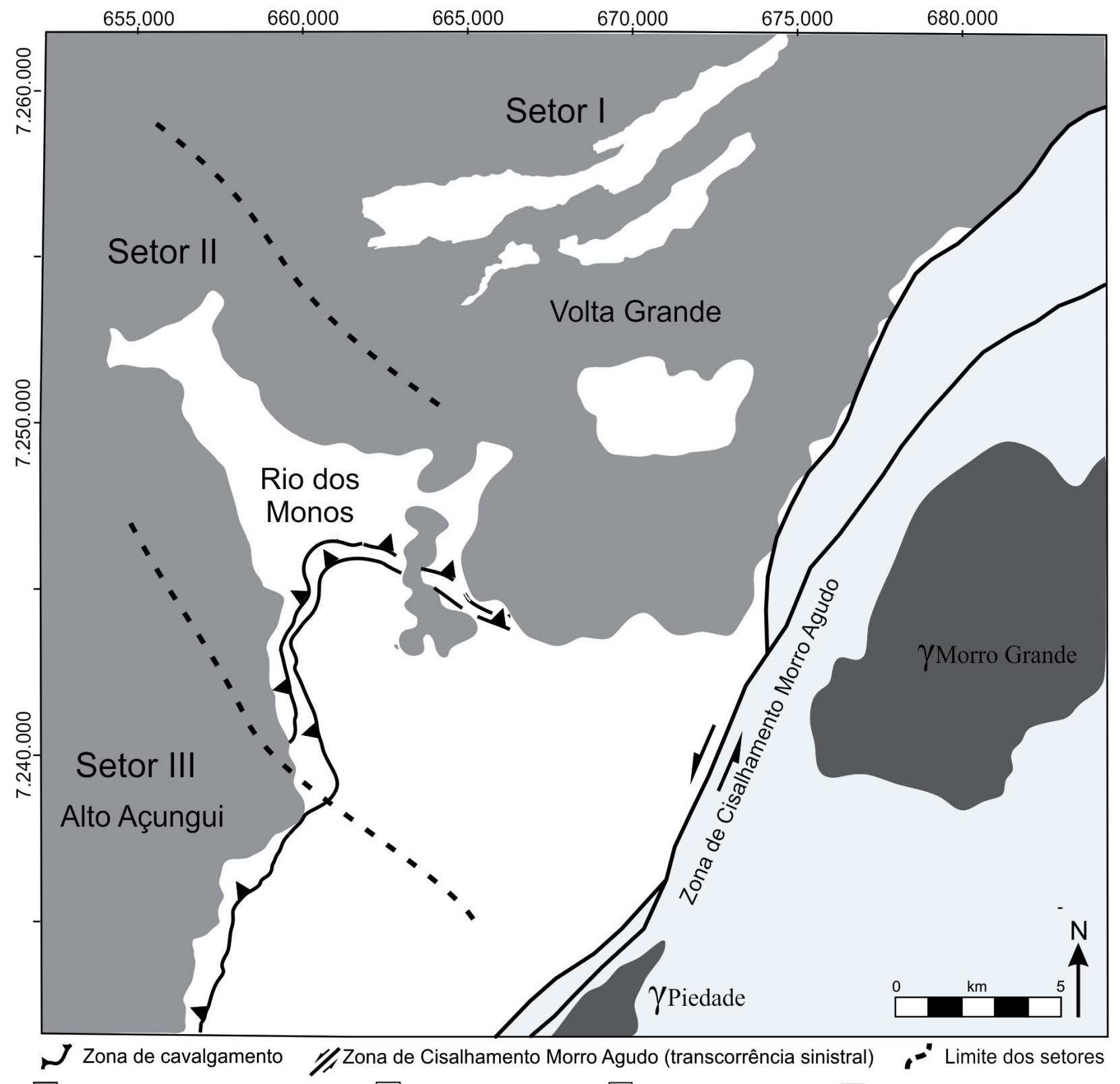

Complexo Granítico Três Córregos $\square$ Formação Água Clara $\square$ Formação Votuverava $\square$ Granitos tardi/pós-tectônicos

Figura 6. Mapa geológico simplificado da área de estudo, com a divisão dos setores estruturais reconhecidos. Os três setores mostram diferenças geológicas na relação granito-encaixante, sendo também caracterizados por variações geométricas na tendência geral da direção das foliações, bem como pela variação no desenvolvimento de $S_{1}, S_{2}$ e $S_{c}$. O Setor I, na região de Volta Grande, apresenta-se com megaenclaves e lascas de rochas metassedimentares com formas alongadas; o Setor II, na região do Rio dos Monos, é caracterizado como uma região onde a borda do Complexo Granítico Três Córregos (CGTC) tem traço irregular, com uma série de reentrâncias e engolfamentos, na direção NW; por fim, o Setor III, do Alto Açungui, registra contato do CGTC com as encaixantes da Formação Água Clara com delineado regular, contudo ainda sinuoso, onde destaca-se a coexistência de estruturas de baixo ângulo tanto nas encaixantes quanto nos granitos. 
rompidos (cabo de guarda-chuva), quartzo ribbons e em formato fish, porfiroblastos sigmoides rotacionados com sombras de pressão simétricas e assimétricas, além do desenvolvimento de foliação $\mathrm{S}-\mathrm{C}$, com baixos valores de mergulho (em média $35^{\circ}$ ).

Essas estruturas caracterizam zonas de cavalgamentos, com geração de zonas miloníticas expressivas na área, responsáveis pela atual estratigrafia das unidades. $\mathrm{O}$ sentido de movimento nelas impresso indica vergência para sudeste.

\section{Foliação $S_{3}$}

A foliação $S_{3}$ não é penetrativa a toda a área, tendo ocorrência restrita à zona de influência da deformação associada à ZCMA. Caracterizada por feições proto a ultramiloníticas, é contínua e anastomosada, definida pela orientação de minerais filossilicáticos finos e estiramento mineral (principalmente quartzo). Em paralelismo com a foliação são observados quartzo associado aribbon, mica fish e boudins de quartzo. A direção geral dessa foliação é N30E, acompanhando o traçado da ZCMA, com mergulhos verticais.
O desenvolvimento de rochas miloníticas se faz ao longo de uma zona de aproximadamente $1,5 \mathrm{~km}$.

Por meio da análise de estereogramas construídos de maneira setorizada, percebe-se que o padrão estrutural das foliações $S_{1}$ e $S_{2}$ observado nas lascas de rochas metassedimentares do Setor I é coerente com o observado nas rochas metassedimentares contínuas, do Setor III (Figura 8), com predomínio de direção N60E e mergulhos $40-70^{\circ}$ para SE e NW, no caso da foliação $S_{1}$; direções N70W/40NE e N50E/35NW para a foliação $S_{2}$ no Setor I; e direções subparalelas entre as foliações no Setor III (foliação $S_{1}$ com máximos em N55E/60NW, e foliação $\mathrm{S}_{2}$, em N70E/40NW), conforme a Figura 9. Os dados estruturais sugerem que tais corpos desconectados não representam tetos pendentes (roof pendants) englobados e desorientados durante o crescimento da câmara magmática, mas que as lascas foram desconectadas por ação tectônica durante a ascensão magmática, mantendo orientação dos corpos, de certo modo, paralela à borda próxima do granito, e padrão de orientação das foliações concordante com o padrão geral das rochas metassedimentares da área de estudo. Vale ressaltar que as lineações de

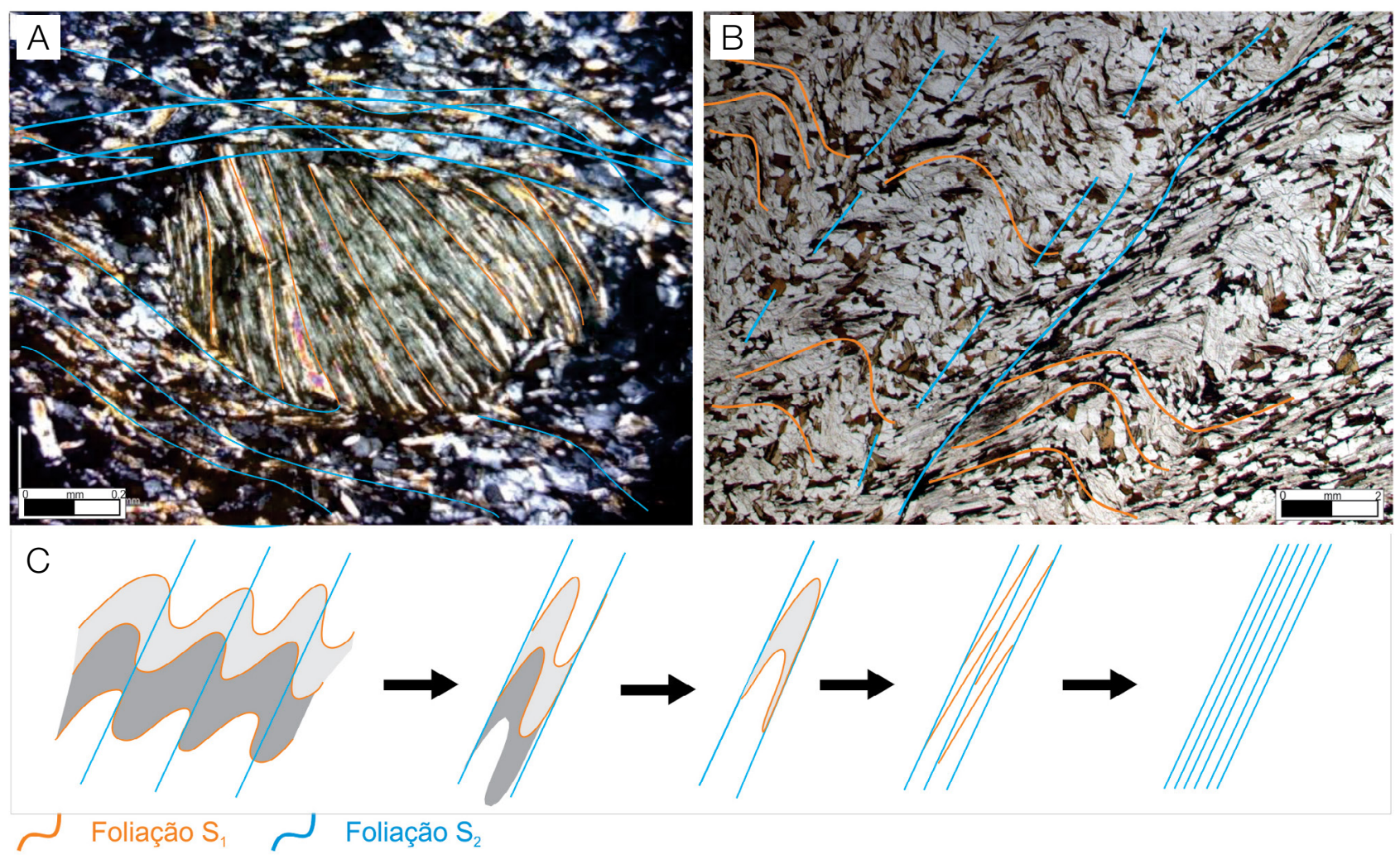

Figura 7. Características e geometria das foliações $S_{1}$ e $S_{2}$. (A) fotomicrografia de micróliton da foliação $S_{2}$ milonítica, com rastro da foliação $S_{1}$ (definida pela orientação de sericita e quartzo); (B) fotomicrografia da foliação $S_{1}$ crenulada, com desenvolvimento de $S_{2}$ como clivagem de crenulação; (C) evolução do sistema de transposição da foliação $S_{1}$ pelo desenvolvimento de $S_{2}$. 
estiramento observadas no Setor III são preferencialmente de mergulho, com máximos entre 285 e $46^{\circ}$ e patíveis com as falhas de cavalgamento observadas na região (Figura 9).

Já o Setor II é fortemente condicionado por dobramento de eixo NW, com distribuição dos dados da foliação em uma guirlanda, na qual nos flancos predominam direções médias
$\mathrm{N} 40 \mathrm{~W}$, com mergulhos baixos para NE e SW, e na região de charneira prevalecem planos de foliação com direção $\mathrm{N} 50 \mathrm{E}$ e mergulhos moderados $\left(40^{\circ}\right)$ para $\mathrm{NW}$, configurando um padrão estrutural divergente em relação aos outros dois setores (Figura 8). Porém, a relação geométrica entre foliações e crenulações é a mesma observada nos demais setores.

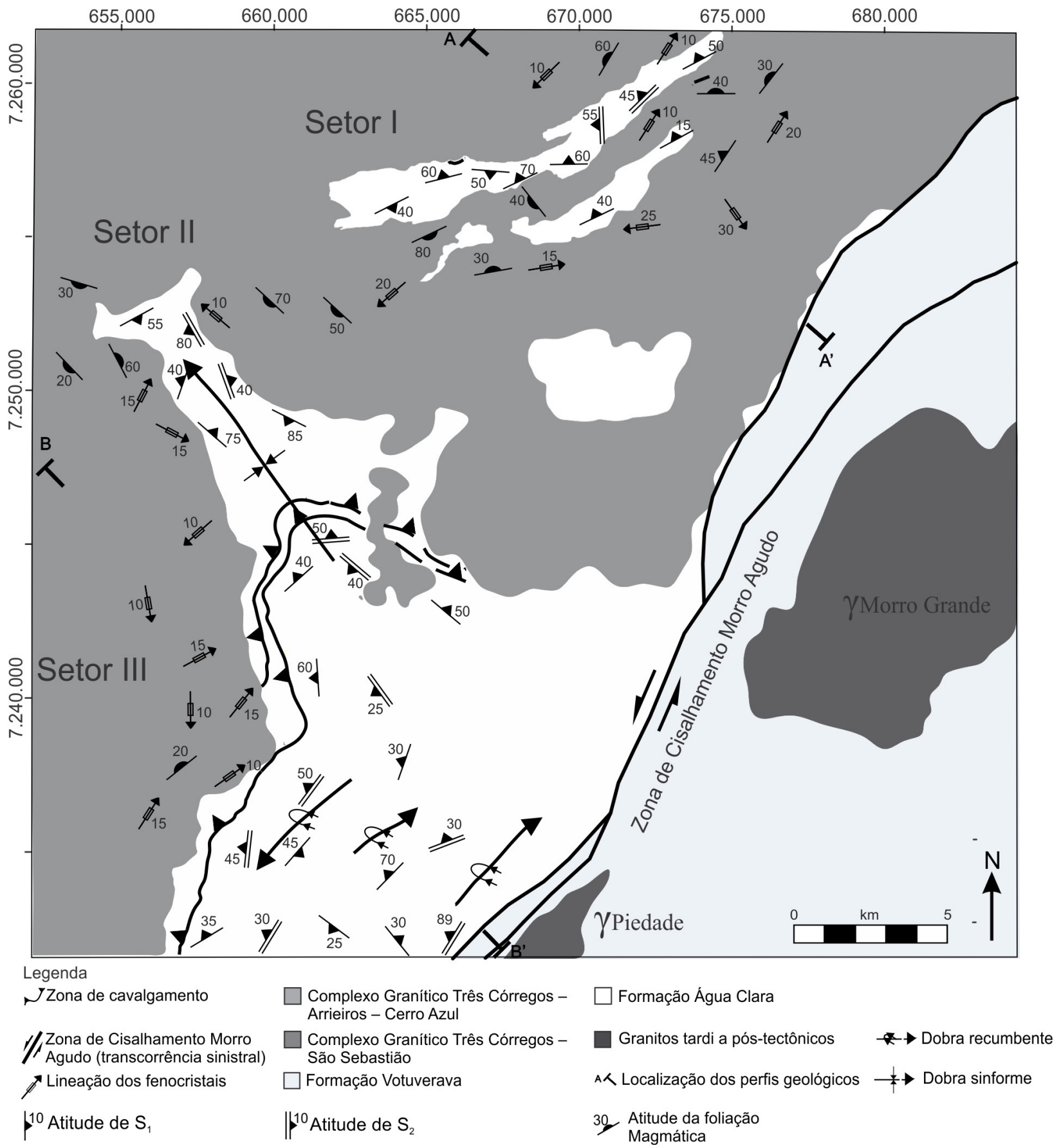

Figura 8. Mapa estrutural da borda leste do Complexo Granítico Três Córregos e das rochas metassedimentares encaixantes. 


\section{Contexto estrutural da borda leste do Complexo Granítico Três Córregos}

A principal estrutura observada nas rochas graníticas da área de estudo é a foliação magmática originada por fluxo, que apresenta principalmente planos desenvolvidos com baixos valores de mergulho, mas localmente observam-se planos subverticais. Porém, essas foliações não foram reconhecidas em todos os afloramentos, refletindo seu desenvolvimento heterogêneo, sendo observados termos graníticos isótropos, com foliação incipiente a fraca e moderada. Em locais restritos podem ser observadas rochas intensamente foliadas como produto de um fluxo magmático sugerindo contexto tectônico compressivo.

A foliação magmática é reconhecida pela orientação dos cristais de biotita e anfibólio em níveis milimétricos, em conjunto com alinhamento de fenocristais de feldspato alcalino, configurando planos irregulares subparalelos, de
A
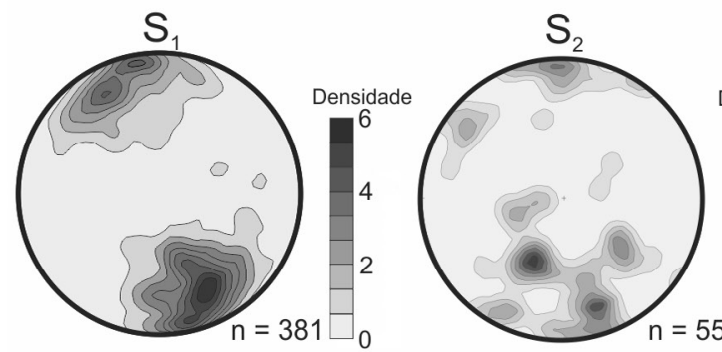

8
6
4
2
0

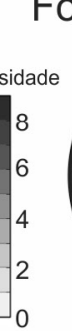

Foliação magmática
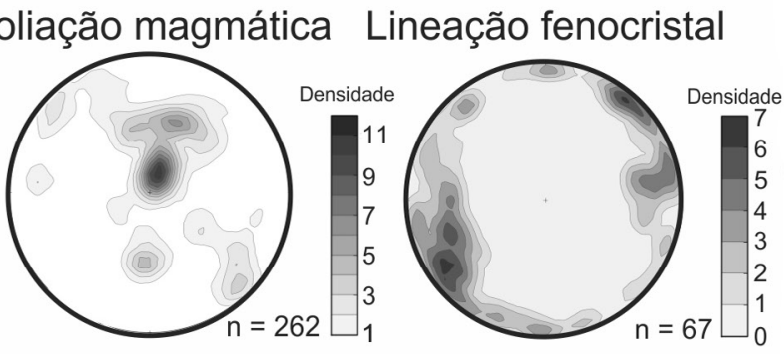

B
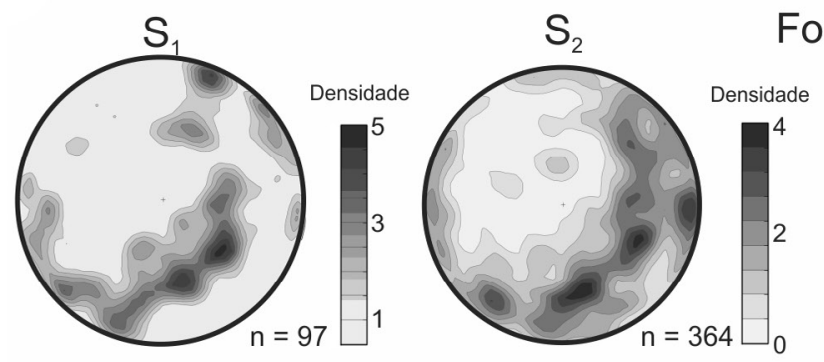

Foliação magmática
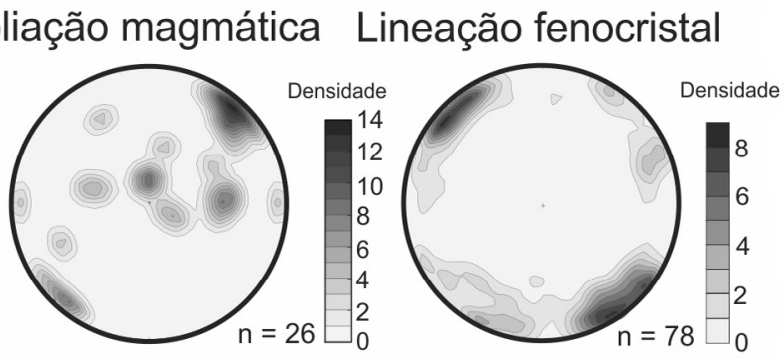

C

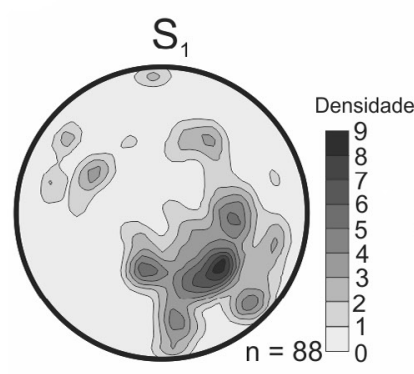

Setor III

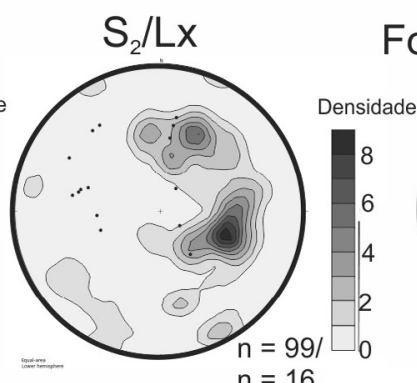

Foliação magmática

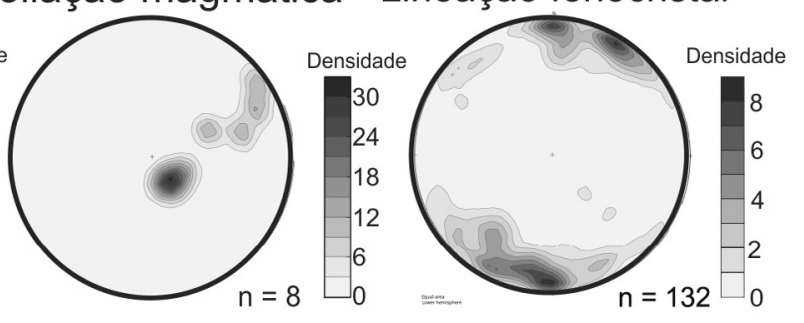

Figura 9. Diagramas Schimidt-Lambert de igual área, das foliações $S_{1}$ e $S_{2}$ observadas nas rochas metassedimentares da Formação Água Clara, e da lineação mineral originada pela orientação de fenocristais de feldspato potássico e foliação de fluxo magmático observadas nos granitos. (A) diagramas estruturais do Setor I; (B) diagramas estruturais do Setor II; (C) diagramas estruturais do Setor III. 
espaçamento milimétrico, em que não são observadas evidências de deformação nos cristais.

Essa foliação apresenta predominantemente baixos valores de mergulho $\left(\mathrm{S}_{\mathrm{g} 1}\right)$ ao longo de toda a borda leste do CGTC, com variações na direção observada nos três setores analisados. Em alguns locais são observados planos de alto ângulo com evidências de uma relação hierárquica que sugere tratar de uma segunda foliação magmática $\left(\mathrm{S}_{\mathrm{g} 2}\right)$, de caráter restrito, com espaçamento métrico, sendo observada somente no Setor III, em que é interpretada uma zona de cisalhamento transcorrente interna ao CGTC.

Assim como nas rochas metassedimentares, por meio da construção de estereogramas da foliação magmática (Figura 9) confirmou-se a existência de três setores estruturais com orientações preferenciais distintas. O setor I é caracterizado pelo predomínio de orientação de fenocristais de feldspato alcalino com direções N40-80E de baixos valores de mergulho $\left(10\right.$ a $\left.30^{\circ}\right)$. Os planos da foliação magmática nesse setor apresentam direção N10-30E, com mergulhos de baixo ângulo (em média $30^{\circ}$ ) para NW, embora ocorram foliações de direção N40W com mergulho baixo $\left(10^{\circ}\right)$ para SW.

No setor II, a orientação de fenocristais apresenta predomínio para $\mathrm{N} 50 \mathrm{~W}$, também com valores baixos de ângulo de mergulho (entre 5 e $30^{\circ}$ ). Nele, há predomínio de planos de foliação magmática também com direção média N50W e baixos valores de mergulho, porém, próximo ao contato com as rochas metassedimentares, os planos da foliação apresentam valores elevados de mergulho, entre 60 e $80^{\circ}$ (Figura 9).

O padrão da orientação dos fenocristais no setor III é marcado pelo predomínio de direções NS a N30E, com baixos valores de mergulho (média de $20^{\circ}$ ). O mesmo predomínio é observado na direção da foliação; contudo, os valores de mergulhos são mais elevados, com caimentos para NW (Figura 9).

\section{METAMORFISMO}

Avaliando o contexto geral, na borda centro-leste do CGTC são observados dois eventos metamórficos principais, com paragêneses que permitem reconhecer as fácies xisto verde, zona da biotita e zona da granada, e fácies anfibolito, zona da estaurolita e zona da sillimanita. A distribuição dessas fácies não permite reconstruir isógradas em toda a área de estudo, sendo que apenas na porção sul, na região do Alto Açungui, podem ser observadas paragêneses distribuídas em uma auréola com aproximadamente $1 \mathrm{~km}$.

Em alguns locais são observados registros de temperatura relativamente mais elevada se comparada ao contexto metamórfico do Terreno Apiaí, sendo observadas paragêneses compatíveis com a zona da sillimanita, caracterizada na região do Alto Açungui, onde são reconhecidas associações minerais com tremolita-biotita-diopsídio que sugerem condições próximas à transição da fácies Anfibolito inferior e superior. Os registros metamórficos dessa fácies nas rochas calciossilicáticas e carbonática apresentam paragêneses diferentes.

O primeiro registro metamórfico $\left(M_{1}\right)$ nas rochas da Formação Água Clara está associado ao desenvolvimento da foliação $S$, sendo observado localmente nos micrólitons da foliação $\mathrm{S}_{2}$. Seu reconhecimento nem sempre é fácil, pois na maioria das vezes suas paragêneses e texturas não se encontram preservadas, em razão da sobreposição do evento $M_{2}$. Os registros observados na área de estudo apontam para um desenvolvimento heterogêneo, representado por minerais índices compatíveis com as fácies xisto verde e anfibolito.

Os minerais de $\mathrm{M}_{1}$ podem ser observados como micas crenuladas em diferentes estilos e alguns porfiroclastos de granada e estaurolita, parcialmente substituídos e aprisionados em micrólitons submilimétricos de $\mathrm{S}_{2}$ São observadas deformações nas clivagens, microdobras, estruturas do tipo strain-slip, na recristalização e transposição de $\mathrm{S}_{1}$. Os cristais de granada são contornados pela foliação $\mathrm{S}_{2}$, muitas vezes com geração de sombra de pressão com cristais de quartzo, indicando o seu crescimento pré-tectônico em relação ao desenvolvimento dessa foliação. Na região do Rio dos Monos são observados cristais de cianita associados ao $\mathrm{M}_{1}$, frequentemente deformados e parcialmente substituídos por micas e quartzo (Figura 10A), refletindo uma possível mudança nas condições de temperatura e pressão entre $M_{1}$ e $\mathrm{M}_{2}$. Ressalta-se que os primeiros estágios de deformação no Terreno Apiaí podem ser reflexos de uma tectônica de baixo ângulo, indicando o desenvolvimento de nappes (Faleiros et al., 2011). Condições de maior pressão podem estar associadas a porções restritas, próximas às zonas de cavalgamento da primeira fase de deformação.

Os cristais de granada são contornados pela foliação $S_{2}$, muitas vezes com geração de sombra de pressão com cristais de quartzo, indicando o seu crescimento pré-tectônico em relação ao desenvolvimento desta foliação, e as inclusões de quartzo não apresentam orientação preferencial, sugerindo desenvolvimento pós-tectônico em relação à S1 e configurando, assim, desenvolvimento intertectônico desses cristais.

Os cristais de estaurolita e andaluzita observados nas rochas pelito-aluminosas da Formação Água Clara ocorrem como porfiroblastos idiomórficos a subidiomórficos. No caso da estaurolita, os porfiroblastos são contornados pela foliação $\mathrm{S}_{2}$, com vértices corroídos, por vezes com geração de sombras de pressão e cristalização de quartzo de granulação média (condicionado pela foliação) (Figura 10B). Nos cristais de estaurolita ainda são observados aspectos de recristalização nas bordas, com quartzo e sericita. Esses porfiroblastos aparentam desenvolvimento pré-tectônico em relação à foliação $S_{2}$. Como a $S_{1}$ foi completamente obliterada pela segunda foliação nessa região, não é possível estabelecer relação temporal entre o desenvolvimento dos porfiroblastos com o da foliação $\mathrm{S}_{1}$. Já os cristais de andaluzita 

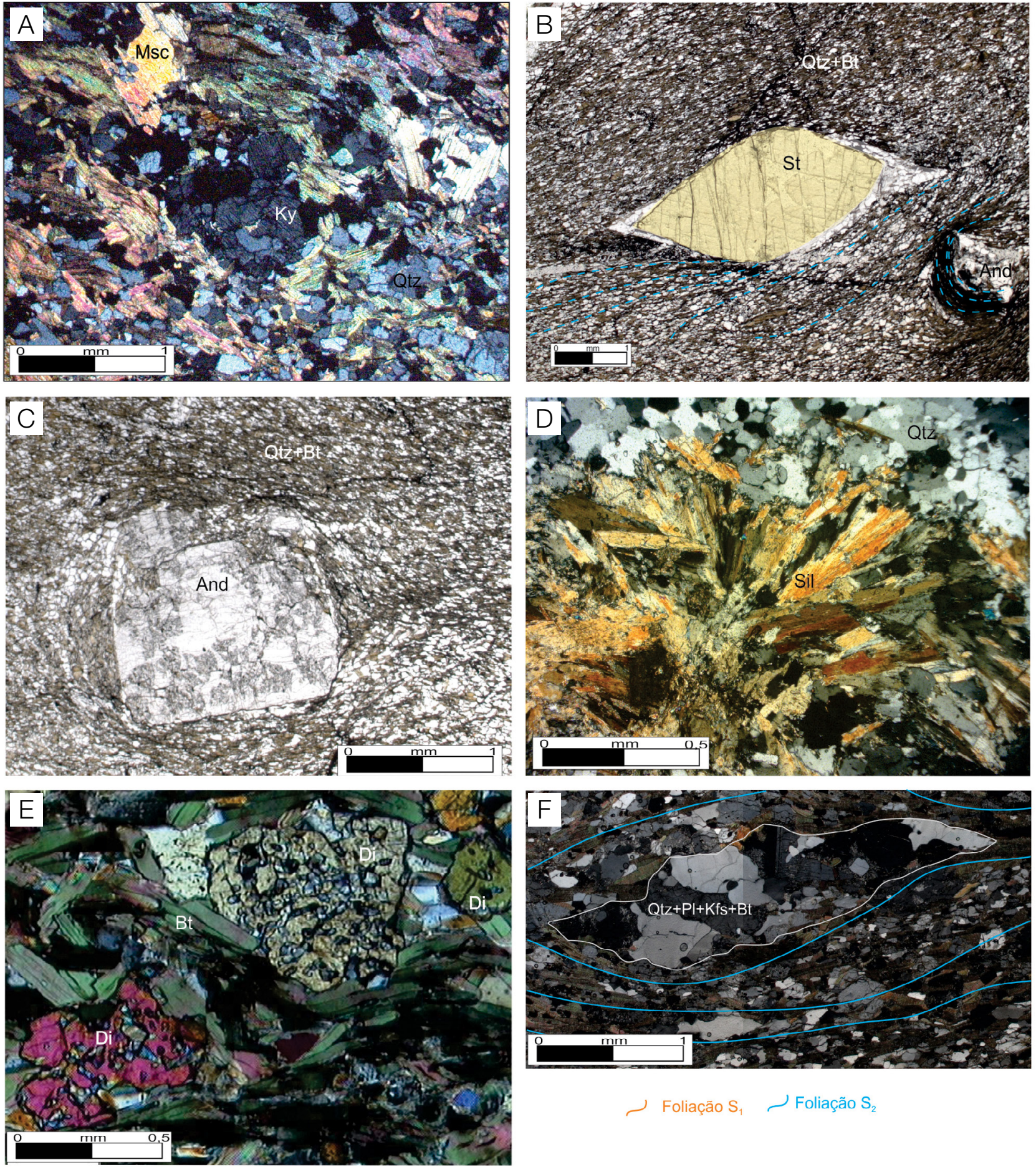

Foliação $S_{2}$

Figura 10. Principais minerais índices das fácies metamórficas reconhecidas. (A) cianita (Ky) desenvolvida associada à foliação $S_{1}$, caracterizando metamorfismo $M_{1}$, parcialmente deformada pelo desenvolvimento da foliação $S_{2}$, polarizadores cruzados; (B) porfiroclasto de estaurolita fish (St), contornado pela foliação $S_{2}$, definido pela orientação de biotita (Bt) e quartzo (Qtz), com desenvolvimento de "sombra de pressão", onde se cristalizou quartzo de granulação média, e porfiroclasto de andaluzita (And) contornado e destruído pela foliação $S_{2}$, polarizadores cruzados; (C) porfiroclasto de andaluzita (And) com vértices corroídos pelo desenvolvimento da foliação $S_{2}$, polarizadores paralelos; (D) cristais de sillimanita (Sil) com aspecto fibrorradiado, associado a evento termal, polarizadores cruzados; (E) diopsídio (Di) parcialmente substituído, contornado pela foliação $S_{2}$, polarizadores cruzados; (F) fotomicrografia de boudins constituídos por quartzo $(\mathrm{Qtz})$, plagioclásio $(\mathrm{PI})$, microclínio $(\mathrm{Kfs})$ e traço de biotita $(\mathrm{Bt})$, com cristais xenomórficos. 
apresentam cantos corroídos, com sombras que sugerem rotação pela foliação $\mathrm{S}_{2}$ em desenvolvimento (Figuras 10B e 10C). Em outros cristais, observa-se a geração de sombra de pressão com recristalização de quartzo poligonal, indicando o caráter pré a intertectônico desses cristais (penecontemporâneos ao desenvolvimento de $\mathrm{S}_{2}$ ).

A sillimanita ocorre nessa região na variação fibrolita, em porfiroblastos contornados e destruídos pela foliação $S_{2}$ (Figura 10D), ou em "feixes" de fibrolita orientados segundo a foliação. A relação geométrica entre os cristais de fibrolita e a foliação $S_{2}$, ora substituindo porfiroblastos reliquiares contornados por ela, ora em feixes orientados, pode indicar a cristalização em caráter sintectônico em relação à $\mathrm{S}_{2}$. Contudo, os cristais de fibrolita substituindo os porfiroblastos podem ter sido gerados antes da deformação associada ao desenvolvimento de $\mathrm{S}_{2}$, sugerindo interpretação alternativa de cristalização intertectônica (entre $\mathrm{S}_{1}$ e $\mathrm{S}_{2}$ ).

A síntese das paragêneses atribuídas a cada fácies metamórfica identificada nos diferentes protólitos permitiu a construção de um sumário com os minerais índices observados nas distintas unidades, expressos no Quadro 1, que ressalta as variações resultantes das diferentes composições dos protólitos. Observa-se que essas rochas ocorrem intercaladas e as diferenças nas condições metamórficas sugeridas pelas paragêneses podem ser observadas dentro de uma mesma unidade.

O segundo evento metamórfico $\left(\mathrm{M}_{2}\right)$ é caracterizado por uma variação do grau metamórfico desde fácies xisto verde zona da biotita, até pelo menos a fácies anfibolito. As rochas calciossilicáticas da região do Rio dos Monos e da Volta Grande podem apresentar associações minerais mais diversificadas, com silicatos de Ca-Mg-Al, sendo a zoisita um dos minerais índices mais comuns. A paragênese comum

Quadro 1. Paragêneses minerais observadas em diferentes protólitos das encaixantes na borda leste do Cinturão Granítico Três Córregos.

\begin{tabular}{|c|c|c|}
\hline $\begin{array}{l}\text { Rochas } \\
\text { carbonáticas e } \\
\text { calciossilicáticas }\end{array}$ & $\begin{array}{c}\text { Rochas } \\
\text { pelito- } \\
\text { aluminosas }\end{array}$ & $\begin{array}{c}\text { Pico } \\
\text { metamórfico }\end{array}$ \\
\hline $\begin{array}{l}\text { calcita, tremolita, } \\
\text { biotita }\end{array}$ & $\begin{array}{c}\text { quartzo, } \\
\text { muscovita, biotita }\end{array}$ & $\begin{array}{c}\text { xisto verde, zona } \\
\text { da biotita }\end{array}$ \\
\hline $\begin{array}{l}\text { calcita, biotita, } \\
\text { zoisita, actinolita }\end{array}$ & $\begin{array}{l}\text { quartzo, } \\
\text { muscovita, biotita, } \\
\text { almandina }\end{array}$ & $\begin{array}{c}\text { xisto verde, zona } \\
\text { da almandina }\end{array}$ \\
\hline $\begin{array}{l}\text { grossulária, } \\
\text { hornblenda, } \\
\text { zoisita }\end{array}$ & $\begin{array}{l}\text { muscovita, biotita, } \\
\text { almandina, } \\
\text { estaurolita, } \\
\text { andaluzita }\end{array}$ & $\begin{array}{c}\text { anfibolito, zona } \\
\text { da estaurolita }\end{array}$ \\
\hline $\begin{array}{l}\text { actinolita, } \\
\text { plagioclásio, } \\
\text { diopsídio }\end{array}$ & $\begin{array}{l}\text { feldspato } \\
\text { potássico, } \\
\text { granada, } \\
\text { sillimanita }\end{array}$ & $\begin{array}{c}\text { anfibolito, zona } \\
\text { da sillimanita }\end{array}$ \\
\hline
\end{tabular}

observada é zoisita \pm biotita \pm hornblenda, que pode ser compatível com as condições de P-T da fácies Anfibolito, zona da estaurolita. Os registros dessa fácies estão localizados em regiões um pouco mais distantes do contato com os granitos, sendo aparentemente controlados pela presença das zonas de cisalhamento de baixo ângulo.

Associadas às zonas de cisalhamento, são encontradas paragêneses indicativas de fácies xisto verde superior, com condições locais que podem chegar à estabilidade da fibrolita, na fácies anfibolito. Nas rochas pelito-aluminosas (xistos e filitos) são observadas associações minerais com muscovita \pm biotita \pm almandina, enquanto nas calciossilicáticas há associações minerais com zoisita \pm biotita \pm granada e zoisita \pm calcita \pm biotita \pm actinolita. Essas paragêneses, sugestivas da fácies xisto verde, zona da almandina, encontram-se distribuídas em todos os setores; contudo, não é possível caracterizar com precisão isógradas na escala do presente trabalho.

Na região de Volta Grande são encontrados registros de paragêneses com calcita \pm tremolita \pm diopsídio, calcita \pm diopsídio e calcita \pm zoisita \pm biotita \pm diopsídio nas rochas calciossilicáticas. Essas paragêneses são compatíveis com a zona da sillimanita, encontrada nas rochas metapelíticas (xistos e filitos). Nos mármores, o diopsídio apresenta formas subédricas a anédricas, concentrado em níveis com maior granulometria que acompanham o bandamento textural. Nas rochas carbonatossilicáticas podem ser observados cristais de diopsídio contornados por cristais de biotita orientados em $\mathrm{S}_{2}$, estando estes parcialmente substituídos por quartzo e epidoto (Figura 9E). Em ambas as situações as rochas estão localizadas em afloramentos próximos aos granitos e reforçam a hipótese de um importante evento termal associado ao desenvolvimento de $\mathrm{M}_{2}$.

A formação do diopsídio em rochas carbonáticas e calciossilicáticas está relacionada a uma reação de descarbonatação e desidratação em condições de temperatura compatíveis com a fácies anfibolito superior, conforme Equação 1:

$\mathrm{Ca}_{2} \mathrm{Mg}_{5} \mathrm{Si}_{8} \mathrm{O}_{22}(\mathrm{OH})_{2}+3 \cdot \mathrm{CaCO}_{3}+2 \cdot \mathrm{SiO}_{2}=$ $\mathrm{CaMgSi}_{2} \mathrm{O}_{6}+\mathrm{H}_{2} \mathrm{O}+3 \cdot \mathrm{CO}_{2}$ (tremolita + calcita + quartzo $=$ diopsídio + água $\left.+\mathrm{CO}_{2}\right)$

Também nas rochas pelito-aluminosas são reconhecidas paragêneses sugestivas de reação de desidratação em metapelitos, em que a formação da sillimanita (Figura 9D) estaria associada à reação da muscovita com o quartzo e perda de água (Equação 2):

$\mathrm{KAl}_{2} \mathrm{SiAlO}_{10}(\mathrm{OH})_{2}+\mathrm{SiO}_{2}=$ $\mathrm{KAlSi}_{3} \mathrm{O}_{8}+\mathrm{Al}_{2} \mathrm{SiO}_{5}+\mathrm{H}_{2} \mathrm{O}$ (muscovita + quartzo $=$ 
Assim, assume-se a hipótese da participação da intrusão do CGTC na geração dessas paragêneses, fornecendo temperatura para as reações de descarbonatação e desidratação.

Ocorrências de wollastonita são descritas em rochas calciossilicáticas localizadas na região do Rio dos Monos (Pinto et al., 2009), no contato com os granitos, em associações minerais com carbonato e diopsídio. Essa paragênese sugere que, localmente, as rochas calciossilicáticas atingiram temperaturas mais elevadas. Contudo, o aspecto de substituição das wollastonitas e a coexistência com biotita-tremolita sugerem metaestabilidade para essa condição.

A caracterização temporal dos porfiroblastos de paragêneses de temperatura elevada como desenvolvidos em caráter intertectônico, ou seja, entre o desenvolvimento de $\mathrm{S}_{1}$ e $\mathrm{S}_{2}$, reforça a hipótese de que a abertura de espaço para acomodação e instalação dos granitos está relacionada aos eventos de tectônica de baixo ângulo registrados na área de estudo (Figura 11).

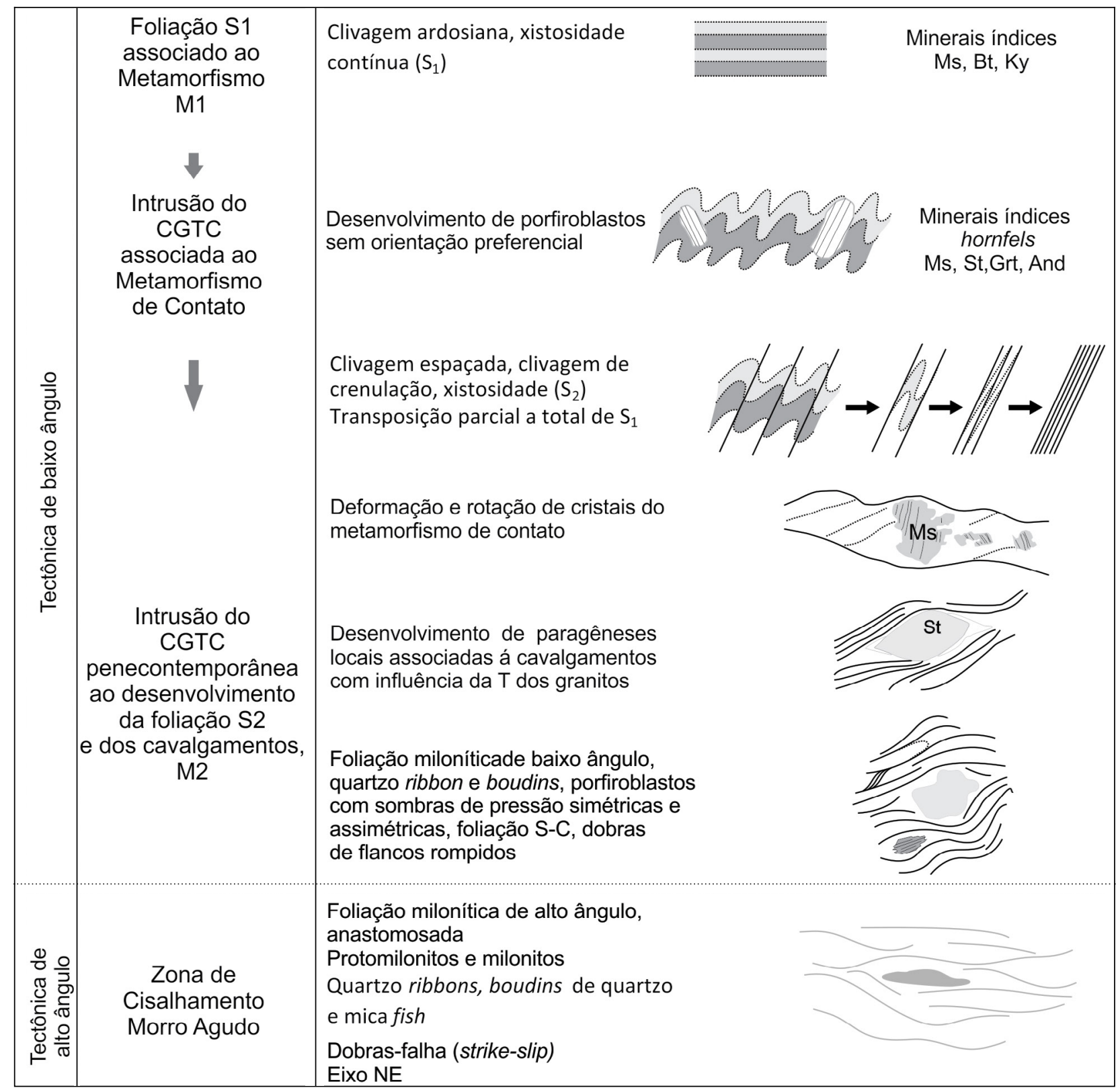

\section{… Foliação S1 $\sim$ Foliação S2 $\sim$ Foliação S3}

CGTC: Cinturão Granítico Três Córregos; T: temperatura.

Figura 11. Síntese da evolução tectônica da borda leste do Cinturão Granítico Três Córregos. 


\section{DISCUSSÃO}

O estudo de cinturões metamórficos é uma tarefa complexa em razão da diversidade dos condicionantes para o desenvolvimento de paragêneses, que dependem tanto das condições de P-T quanto das intrínsecas dos protólitos. A heterogeneidade composicional e a presença de fluidos podem controlar o desenvolvimento de sequências de cristalização completas, o que pode resultar em paragêneses heterogêneas, estáveis em um campo de equilíbrio dinâmico. A variação composicional observada nas encaixantes, resultante de protólitos pelito-aluminosos, carbonáticos e calciossilicáticos, fornece um contexto interessante para o estudo do metamorfismo, pois possibilita o desenvolvimento de paragêneses diferentes. Esse contexto implica na dificuldade de reconhecimento de texturas hornfels nos distintos metassedimentos da área.

Contudo, o maior desafio está em desvendar todas as fontes de temperatura e condições de pressão atuantes na construção de um orógeno, em que as explicações para o desenvolvimento das zonas metamórficas podem estar relacionadas a intrusões ígneas e ao desenvolvimento de zonas de cisalhamento. Em orógenos relacionados à subducção, a compreensão do gradiente metamórfico depende do entendimento dos mecanismos de colocação das rochas graníticas. Nesse contexto, a identificação do padrão estrutural dos litotipos da área de estudo é de suma importância, sendo caracterizado por uma xistosidade contínua $\left(\mathrm{S}_{1}\right)$ penetrativa, heterogeneamente preservada nos micrólitons da segunda xistosidade $\left(\mathrm{S}_{2}\right)$, desenvolvida em um sistema de transposição, associada às faixas miloníticas em zonas de cavalgamento, nas quais a deformação apresenta heterogeneidades, com geração de ultramilonitos, milonitos e protomilonitos de maneira irregular.

O padrão da foliação de fluxo magmático observada nas fácies da borda leste do CGTC é concordante com o observado nas rochas metassedimentares, em especial à $\mathrm{S}_{2}$, em cada setor estrutural analisado, com direções predominantemente NE nos setores I e III e direções NW no setor III. A análise das foliações e lineações sugere que os processos de colocação da borda leste do CGTC estão relacionados a uma tectônica de baixo ângulo, com importantes variações nos diferentes setores estudados. Essas variações são expressas principalmente pela $\mathrm{S}_{1} \mathrm{e}$ $\mathrm{S}_{2}$ nas encaixantes e lineações minerais nos granitos, refletindo diferentes posições de $\sigma 1$ no contexto dos setores Volta Grande, Rio dos Monos e Alto Açungui, reflexo da evolução contemporânea das fácies Arrieiros - Cerro Azul e São Sebastião com as fases de deformação de baixo ângulo.

A dobra de eixo NW, observada na região do Rio dos Monos, tem origem relacionada a uma variação local na tensão, ligada à busca de abertura de espaço durante a colocação dos monzogranitos porfíriticos da fácies São Sebastião. A instalação dessas rochas é penecontemporânea a novo pulso magmático da fácies Arrieiros - Cerro Azul, e esses corpos atuaram como anteparo, resultando no encurtamento da faixa metassedimentar existente entre elas, afetando os cavalgamentos da fase anterior. Nessa região, a foliação magmática de fluxo observada nas duas fácies graníticas apresenta valores de mergulho elevado $\left(\sim 70^{\circ}\right)$, concordante com os contatos entre as rochas graníticas e suas encaixantes, bem como com arranjo estrutural característico dos metassedimentos nesse setor.

As variações no gradiente metamórfico, expressas por paragêneses metamórficas contrastantes na borda leste do CGTC, podem ser reflexo de um metamorfismo progressivo, com influência de temperatura dos granitos do complexo. Tais observações levantam a possibilidade da formação de diferentes zonas metamórficas em distintos setores da faixa de dobramentos, com variação no gradiente geotérmico controlado por contextos locais, como a intrusão de granitos e o desenvolvimento de zonas de cisalhamento.

A sequência de xistos verdes na área de estudo apresenta influência térmica das intrusões graníticas relacionadas à evolução do CGTC. O pico de temperatura dependeu, em grande parte, da proximidade dos granitos e das zonas de cavalgamento, controlando a distribuição das paragêneses metamórficas. Nesse contexto, as intrusões sequenciais das fácies Arrieiros - Cerro Azul e São Sebastião produziram eventos de grau mais elevado relativamente breves em meio à evolução da tectônica de baixo ângulo no Terreno Apiaí, originando um mecanismo para a geração de texturas hornfels sobrepostas por texturas xistosas.

\section{CONCLUSÃO}

Os estágios iniciais da deformação do Terreno Apiaí ocorreram associados à tectônica de baixo ângulo, onde se desenvolveram as foliações $S_{1}$ e $S_{2}$, registradas nas rochas metassedimentares da Formação Água Clara. No contexto dos granitos da borda leste do CGTC, predominam baixos ângulos de mergulho da foliação de fluxo magmático, mesmo nas regiões próximas ao contato com as encaixantes, em que valores de mergulho mais elevados seriam esperados, indicando, assim, que durante a instalação desses granitos, a condicionante tectônica atuante refletia condições de baixo ângulo. As paragêneses metamórficas registradas nas rochas da Formação Água Clara também suportam essa hipótese, tendo sido geradas sob condições de pressão e temperatura compatíveis com a sobreposição dos processos de emplacement do CGTC e da instalação das zonas de cavalgamento. 


\section{AGRADECIMENTOS}

Os autores agradecem à Universidade Federal do Paraná, em especial ao Programa de Pós-Graduação em Geologia, do Departamento de Geologia, por toda a infraestrutura ofertada para o desenvolvimento da pesquisa; ao Laboratório de Análises de Minerais e Rochas (LAMIR - UFPR) e ao Laboratório de Análise de Bacias (LABAP - UFPR) por todo o apoio logístico para a realização dos trabalhos de campo; à Companhia de Pesquisa de Recursos Minerais (CPRM) pela liberação dos dados do levantamento aerogeofísico; ao Laboratório de Pesquisas em Geofísica Aplicada (LPGA UFPR) pelo processamento dos dados; e aos revisores, pelas valiosas contribuições.

\section{REFERÊNCIAS}

Basei, M. A. S., Siga Jr, O., Machiavelli, A., Mancini, F. (1992). Evolução tectônica dos terrenos entre os cinturões Ribeira e Dom Feliciano (PR-SC). Revista Brasileira de Geociências, 22(2), 216-221.

Brown, M. (2009). Metamorphic patterns in orogenic systems and the geological record. In: P. A. Cawood, A. Kröner (Eds.). Accretionary Orogens in Space and Time (37-74). Geological Society, London, Special Publications, 318.

Campanha, G. A. C. (2002). O papel do sistema de zonas de cisalhamento transcorrentes na configuração da porção meridional da Faixa Ribeira. Tese (Livre Docência em Mineralogia e Geotectônica). São Paulo: Instituto de Geociências - USP.

Companhia de Pesquisa de Recursos Minerais (CPRM). (2011). Projeto Aerogrofisico Paraná-Santa Catarina (PR, SC, $S P)$. Comunicado sobre a disponibilização de dados digitais aerogeofísicos (Magnetometria e Gamaespectrometria). Brasília: Ministério de Minas e Energia.

Cury, L. F., Siga Jr., O., Harara, O. M. M., Prazeres Filho, H. J., Basei, M. A. S. (2008). Aspectos tectônicos das intrusões dos granitos do Cerne, Passa Três e Rio Abaixo, sudeste do Pré-Cambriano paranaense. Estudo baseado em datações ${ }^{39} \mathrm{Ar}-{ }^{40} \mathrm{Ar}$ em micas. Geologia USP. Série Cientifica, 8(1), 87-104.

De Yoreo, J. J., Lux, D. R., Guidotti, C. V. (1991). Thermal modeling in low-pressure'high-temperature metamorphic belts. Tectonophysics, 188:209-238.

Faleiros, F. M., Campanha, G. A. C., Bello, R. M. S., Fuzikawa, K. (2010). Quartz recrystallization regimes, $c$-axis texture transitions and fluid inclusion reequilibration in a prograde greenschist to amphibolite facies mylonite zone (Ribeira Shear Zone, SE Brazil). Tectonophysics, 485, 193-214.

Faleiros, F. M., Campanha, G. A. C., Martins, L., Vlach, S. R. F., Vasconcelos, P. M. (2011). Ediacaran high-pressure collision metamorphism and tectonics of the southern Ribeira Belt (SE Brazil): evidence for terrane accretion and dispersion during Gondwana assembly. Precambrian Research, 189, 263-291.

Faleiros, F. M., Morais, S. M., Costa, V. S. (2012). Geologia e recursos minerais da Folha Apiai - SG.22-X-B-V, Estados de São Paulo e Paraná. Escala 1:100.000. São Paulo: CPRM. 107p.

Fassbinder, E. (1996). A unidade Água Clara no contexto do Grupo Açungui: um modelo transpressivo de colisão oblíqua no Neoproterozóico paranaense. Tese (Doutorado). São Paulo: Instituto de Geociências - USP.

Fritzsons Jr., O., Piekarz, G. F., Falcade, D. (1982). Geologia e potencial econômico do Grupo Setuva (PR). XXXII Congresso Brasileiro de Geologia, 3, 987-1001. Salvador: SBG.

Fuck, R. A., Trein, E., Marini, O. J. (1967). Contribuição ao estudo das rochas graníticas do Estado do Paraná. Boletim Paranaense de Geociências, 23/25, 183-219.

Gimenez Filho, A. (1993). Evolução do Complexo Granítico Três Córregos. Dissertação (Mestrado). São Paulo: Instituto de Geociências - USP.

Gimenez Filho, A., Teixeira, W., Figueiredo, M. C. H., Trevizoli Jr., L. E. (1995). Geologia, Petrografia e litogeoquímica do Complexo Granítico Três Córregos na região de Barra do Chapéu e Ribeirão Branco, SP. Revista Brasileira de Geociências, 25(2), 92-106.

Grohmann, C. H., Campanha, G. A. C. (2010). OpenStereo: open source, cross-platform software for structural geology analysis. Acesso em: fevereiro de 2012, <http://www.igc. usp.br/index.php?id=395>.

Hanson, R. B. (1995). Role of fluid flow in the contact metamorphism of siliceous dolomitic limestones-Discussion. American Mineralogist, 80, 1222-1225.

Hanson, R. B., Barton, M. D. (1989). Thermal development of low-pressure metamorphic belts: Results from twodimensional numerical models. Journal of Geophysical Research: Solid Earth, 94, 10363-10377. 
Hasui, Y. (2012). Sistema Orogênico Mantiqueira. In: Y. Hasui, C. D. R. Carneiro, F. F. M. Almeida, A. Bartorelli (Eds.). Geologia do Brasil (v.1, 331-372). São Paulo: Beca.

Heilbron M., Machado N. (2003). Timing of terrane accretion in the Neoproterozoic-Eopaleozoic Ribeira orogen (SE Brazil). Precambrian Research, 125, 87-112.

Heilbron, M., Pedrosa-Soares, A. C., Campos Neto, M. C., Silva, L. C., Trouw, R. A. J., Janasi, V. A. (2004). Província Mantiqueira. In: V. Mantesso-Neto, A. Bartorelli, C. D. R. Carneiro, B. B. Brito-Neves (Eds.). Geologia do continente sul-americano: evolução da obra de Fernando Flávio Marques de Almeida (v. 1, 203-234). São Paulo: Beca.

Heilbron, M., Valeriano, C. M., Tassinari, C. C. G., Almeida, J. C. H., Tupinambá, M., Siga Jr., O., Trouw, R. J. A. (2008). Correlation of Neoproterozoic terranes between the Ribeira Belt, SE Brazil and its African counterpart: comparative tectonic evolution and open questions. In: R. J. Pankhurst, R. A. J. Trouw, B. B. Brito Neves, M. J. de Wit (Eds.). West Gondwana Pre-Cenozoic Correlations Across the South Atlantic Region, (v. 294, 211-237). Londres: The Geological Society of London.

Janasi, V. A., Leite, R. J., Van Schmus W. R. (2001). U-Pb chronostratigraphy of the granitic magmatism in the Agudos Grandes Batholith (W of São Paulo, Brazil) - implications for the evolution of the Ribeira Belt. Journal of South American Earth Sciences, 14(4), 363-376.

Marini, O. J. (1970). Geologia da Folha de Rio Branco do $\mathrm{Sul}$. Tese (Doutorado). Rio Claro: Faculdade de Filosofia, Ciências e Letras - UNESP.

Marini, O. J., Trein, E., Fuck, R. A. (1967). O Grupo Açungui no estado do Paraná. Boletim Paranaense de Geociências, Série Especial, 23, 43-104.

Passchier, C. W., Trouw, R. A. J. (2005). Microtectonics. Berlin: Springer Verlag. 366p.

Pinto, F. M., Gomes, M. V., Freitas, T. M. (2009). Relatório do Mapa Geológico da região do Ribeirão dos Monos (Cerro Azul-PR). Relatório Interno. Curitiba: Departamento de Geologia, UFPR.

Pontes, J. B. (1982). Geologia e potencialidades econômicas da Formação Água Clara (PR). XXXII Congresso Brasileiro de Geologia, 3, 1002-1016. Salvador: SBG.

Prazeres Filho, H. J. (2000). Litogeoquímica, geocronologia $(\mathrm{U}-\mathrm{Pb})$ e geologia isotópica dos complexos graníticos
Cunhaporanga e Três Córregos, estado do Paraná. Dissertação (Mestrado). São Paulo: Instituto de Geociências - USP.

Prazeres Filho, H. J. (2005). Caracterização geológica e petrogenética do Batólito Granítico Três Córregos (PR$\mathrm{SP}$ ): Geoquímica isotópica (Nd-Sr-Pb), idades (ID-TIMS/ SHRIMP) e $\delta^{18} \mathrm{O}$ em zircão. Tese (Doutorado). São Paulo: Instituto de Geociências - USP.

Prazeres Filho, H. J., Harara, O. M. M., Basei, M. A. S., Passarelli, C. R., Siga Jr., O. (2003). Litoquímica, geocronologia $\mathrm{U}-\mathrm{Pb}$ e geologia isotópica ( $\mathrm{Sr}-\mathrm{Nd}-\mathrm{Pb})$ das rochas graníticas dos batólitos Cunhaporanga e Três Córregos na porção sul do Cinturão Ribeira, estado do Paraná. Geologia USP. Série Científica, 3, 51-70.

Salazar, C. A., Archanjo, C. J., Rodrigues, S. W. O., Hollanda, M. H. B. M., Liu, D. (2013). Age and magnetic fabric of the Três Córregos granite batholith: evidence for Ediacaran transtesion in the Ribeira Belt (SE Brazil). International Journal of Earth Sciences, 102, 1563-1581.

Schmitt, R. S., Trouw, R. A. J., Van Schmus, W. R., Pimentel, M. M. (2004). Late amalgamation in the central part of Western Gondwana: new geochronological data and the characterization of a Cambrian collision orogeny in the Ribeira Belt (SE Brazil). Precambrian Research, 133, 29-61.

Schöll, W. U., Silva, A. C. G. A., Monastier, M. S. (1982). A Formação Setuva do Pré-Cambriano do estado do Paraná. XXXII Congresso Brasileiro de Geologia (v.1, 55-63). Salvador: SBG.

Siga Jr., O. (2010). Geocronologia da porção sul do Terreno Apiai: Implicações Tectônicas. Tese (Livre Docência em Mineralogia e Geotectônica). São Paulo: Instituto de Geociências - USP.

Siga Jr., O., Basei, M. A. S., Reis Neto, J. M., Machiavelli, A., Harara, O. M. M. (1995). O Complexo Atuba: um Cinturão Paleoproterozóico intensamente retrabalhado no Neoproterozóico. Geologia USP. Série Científica, 26, 69-98.

Siga Jr., O., Basei, M. A. S., Sato, K., Passarelli, C. R., Nutman, A., McReath, I., Prazeres Filho, H. J. (2011). Calimmyan (1.50-1.45 Ga) magmatic records in Votuverava and Perau sequences, south-southwestern Brazil: zircon ages and Nd-Sr isotopic geochemistry. Journal of South American Earth Science, 32, 301-308.

Siga Jr., O., Basei, M. A. S., Sato, K., Prazeres Filho, H. J., Cury, L. F., Weber, W., Passareli, C. R., Harara, O. M. M., Reis Neto, J. M. (2003). U-Pb (Zircon) Ages of metavolcanic rocks from the Itaiacoca Group: Tectonic Implications. Geologia USP. Série Científica, São Paulo, 3, 39-49. 
Silva, A. T. S. F., Algarte, J. P. (1981). Projeto integração e detalhe geológico no Vale do Ribeira: relatório final de integração geológica. São Paulo: DNPM/CPRM. 15v.

Trouw, R. A. J., Passchier, C. W., Wiersma, D. J. (2010). Atlas of Mylonites-and related microstructures. Berlin: Springer Verlag. 322p.

Vernon, R. H. (2004). A Practical Guide to Rock Microstructure. Cambridge: Cambridge University Press. 594p.
Weber, W., Siga Jr., O., Sato, K., Reis Neto, J. M., Basei, M. A., Nutman, A. P. (2004). A formação Água Clara na região de Araçaíba - SP: Registro U-Pb de uma bacia mesoproterozóica. Geologia USP. Série Cientifica, 4(1),101-110.

Zanella, R. R. (2016). Aspectos estruturais e metamórficos da borda leste do Cinturão Granítico Três Córregos. Dissertação (Mestrado). Curitiba: Universidade Federal do Paraná. 